\title{
ACCESSION AND ORIGINAL OWNERSHIP
}

\author{
Thomas W. Merrill
}

\begin{abstract}
Although first possession is generally assumed to be the dominant means of establishing original ownership of property, there is a second but less studied principle for initiating ownership, called accession, which awards new resources to the owner of existing property most prominently connected to the new resource. Accession applies across a wide variety of areas, from determining rights to baby animals and growing crops to determining ownership of derivative rights under intellectual property laws. Accession shares common features with first possession, in that both principles assign ownership uniquely in a way that imposes minimal information cost burdens on society. But accession differs from first possession in that it does not presuppose that rights are established in an open access commons and does not require the performance of an act to establish ownership. These features of accession make it, as a rule, more efficient than first possession, at least where property rights are thick and securely enforced. More broadly, accession can be seen as the critical legal principle that generates the internalization function of property, insofar as gains and losses attributable to the management of resources are automatically assigned to the most prominently connected property by accession. Although the story of accession is generally a positive one from an efficiency perspective, it may be more problematic from several normative perspectives, which are briefly considered.
\end{abstract}

\section{INTRODUCTION}

Most objects we own as property have been acquired from someone else through consensual transactions, such as purchase, gift, or inheritance. In these situations the things we acquire were recognized to be property in the hands of the person from whom we acquired them. In certain more unusual circumstances, we acquire things through nonconsensual transactions, such as

1 Professor, Yale Law School. Thanks to participants in faculty workshops at Berkeley, Colorado, Columbia, Iowa, Harvard, and Virginia law schools for feedback on earlier drafts. I am especially grateful to Bob Cooter, Mel Eisenberg, Einer Elhauge, Kent Greenwalt, Liz Magill, Rob Merges, Henry Smith, Claire Priest, and Tim Wu for their comments. Brent Kingsbury and Gina Cora provided valuable research assistance. 
adverse possession, forfeiture, or eminent domain. Yet in these cases, too, the objects we acquire as property were recognized to be property in the hands of the person from whom they were taken. Perhaps the most enduring question in property is how these various chains of title-whether based on consensual or nonconsensual transactions-get started. How do objects that are not recognized as property or are thought to have no owner enter the universe of owned objects?

The dominant understanding, especially in the Anglo-American tradition, is that original ownership is established by first possession (Epstein 1979; Lueck 1995). Resources are imagined as originally existing in an open-access commons or the public domain. Individuals acquire property rights in some portion of this common pool by being the first to reduce particular things to possession. John Locke's famous account of the origins of property looms large here. Locke posited that "in the beginning all the World was America" (Locke, 301), by which he meant a world rich in natural resources and thinly populated by people who survived by hunting, fishing, or gathering acorns in the forest.

This article challenges first possession's claim to preeminence as the method of establishing original title to property. There is a second, distinct way of initiating ownership, which I call the principle of accession. The principle of accession holds that ownership is established by assigning resources to the owner of some other thing that is already owned. Examples include the understanding that newborn animals belong to the person who owns the newborn's mother, that minerals discovered under the ground belong to the owner of the surface estate, and that interest paid on a deposit of money belongs to the owner of the principal. First possession and accession have distinct spheres of application. Yet in some circumstances either principle could be used to resolve a dispute over original title. In these areas of overlap, accession rather than first possession tends to prevail. Further, as property rights become thicker and economic values associated with resources become larger, accession increasingly dominates first possession.

The principle of accession once commanded the attention of thinkers of the first rank. Hugo Grotius, Samuel Pufendorf, and David Hume all had interesting things to say about accession. This tradition has died out, at least in English language literature about property rights. One aspiration of this article is to revive interest in accession, with particular focus on how the principle both complements and competes with first possession as a means of establishing original ownership. 
The article is organized as follows. Part I provides an overview of the principle of accession in Anglo-American law. This is designed to show the ubiquity and importance of accession in initiating chains of title, as well as to suggest that accession tends to trump first possession when the two overlap.

Part II considers some of the ways in which accession complements first possession. Both principles provide a foundation for a system of property rights by bringing unclaimed or contested resources under the control of a singular owner-gatekeeper. This assigns managerial authority over resources in an unambiguous fashion and permits resources to be reallocated through transfers so they end up in the hands of those who can extract the most value from them. Significantly, both strategies rely on simple rules that are easily observed and understood and hence are largely self-applying. Therefore, both principles appear to satisfy the very exacting information cost constraints that must be observed for any system of property rights to function.

Part III addresses some critical differences between first possession and accession, which might explain why accession seems to dominate first possession in contexts where they overlap or where property rights are thick and well-established. First possession assigns resources based on a competition among claimants, whereas accession assigns resources to those likely to be competent mangers of the resource. The competitive nature of first possession, together with its background assumption that resources exist in an open access commons, generates a number of familiar pathologies: excessive racing behavior, commons tragedies, inadequate incentives to invest in the common pool, and barriers to collective action. Significantly, each of these pathologies is avoided or reduced if we award original ownership by accession. First possession can occasionally be superior where the owner of the primary asset has limited ability to control or exploit the derivative asset or where first possession generates lower administrative costs. But as property systems become more developed, accession increasingly displaces first possession.

Part IV develops the most far-reaching economic justification for accession: it is the legal principle that generates the internalization function we associate with the institution of property. In its broadest application, the principle of accession means that all gains and losses associated with the management of resources are assigned to the owner of the most prominently connected property. This automatic sweeping function ensures that the gains and losses attributable to management decisions regarding 
assets are assigned to the owner of those assets, no questions asked. Like all rules, this automatic assignment of gains and losses is overbroad. It means that owners of existing resources experience windfall gains and losses that have nothing to do with their management prowess, as when oil is discovered under the family farm. But the rule of automatic assignment has a powerful incentive effect on owners because it means that gains and losses that are attributable to managerial prowess are always captured, too. This internalization feature is critical to the general efficiency of property rights; consequently accession is critical to the efficiency of property rights.

Part V offers some observations about the implications of accession for normative evaluations of the institution of property. Because the principle of accession assigns ownership of new or unclaimed resources based on the status of being an existing property owner, it complicates the standard Lockean defense of private property grounded in a sequence of volitional acts starting with first possession. Accession also complicates egalitarian theories, insofar as accession creates a multiplier effect enhancing the wealth of owners of discrete assets that does not apply to those who have only a claim on a general share of societal resources. Finally, accession contributes to an expanding sphere of property and a concomitant shrinking of the public domain. If one believes that there is inherent value in preserving the public domain-a proposition widely endorsed today by many intellectual property scholars-then accession has problematic consequences for this reason, too.

\section{THE DOMAIN OF ACCESSION}

The principle of first possession is universally recognized as one way of establishing original ownership. First possession is grounded in a conception of being the first to possess some object that is unowned. Valuable resources are regarded as originally existing in an open access commons or the public domain ${ }^{2}-$ a state of affairs in which valuable resources exist but no one has ownership over them. Ownership is awarded to the first person who

2 Commons is potentially misleading here because most physical spaces that have been called the commons or a common are in fact restricted to members of particular communities and are governed by social norms if not legal rules and regulations (Eggertsson; Ostrom). I will use commons and open access interchangeably to refer to a condition in which valuable resources are unowned and are regarded as being up for grabs by the first taker. 
demonstrates a sufficient degree of control over some portion of these resources to be deemed to be in "possession" of them. The acts that qualify as possession are understood to vary according to social context (Ellickson, 1989).

My central claim in this article is that there is a second mechanism for establishing original ownership, which I call the principle of accession. Accession is grounded in a conception of original title as an attachment to existing ownership rights. Typically, valuable things are regarded as existing in a background condition occupied by preexisting property rights. When new resources are discovered or changes in relative values cause previously ignored questions of ownership to become salient, the newly discovered or newly salient resource is awarded to the person who owns as property some other resource prominently connected with the newly discovered or salient thing. The factors that establish prominent connection, in a fashion analogous to those that establish first possession, also vary according to social context.

One can describe the difference between first possession and accession metaphorically. First possession can be said to assign ownership based on the outcome of a race. Various claimants compete to be first to establish control over some valuable prize, like the Sooners galloping off at the sound of a gun to be the first to claim to some tract of land in the Oklahoma territory (Anderson and Hill 2002). Accession operates like a magnet. Imagine that the contested object is like an iron pellet dropped on a table covered by various magnets; the pellet moves toward and becomes affixed to the magnet that exerts the strongest magnetic force on it, as determined by the size and power of the magnets as well as their physical proximity to the pellet. Similarly, prominent connection for purposes of accession is a function not merely of physical proximity but also other forces (mass, for example) that enter into our perception of what it means to say that something has a prominent connection to something else.

The principle of accession was well known to the Romans and was discussed by early English writers, including Bracton, Hume, and Blackstone. Today, the principle has almost entirely disappeared from the English language literature on property rights. ${ }^{3} \mathrm{I}$ am not sure what accounts for this obscurity. One possible explanation has to do with terminology. Around the turn

3 To take but one example, Holmes, in the chapter on "Possession" in his influential lectures on the common law, omitted any reference to accession as a mode of acquiring original ownership of property (Holmes 192-94). 
of the twentieth century, the word accession came to be associated primarily with certain narrow doctrines dealing with mistaken improvers of personal property. ${ }^{4}$ This may have masked the general principle of accession, which as we shall see, applies much more broadly. Another and related explanation is that the narrow doctrine is covered by article nine of the Uniform Commercial Code, which might have led scholars to regard the subject as belonging to commercial law. ${ }^{5}$

If accession is distinct from first possession as a basis for establishing original ownership, how important is this principle in actual property systems? Accession is extremely widespread; indeed, I will argue it is ubiquitous.

\section{A. Traditional Examples}

The operation of accession is easiest to grasp in relatively elemental contexts. After we see the principle of accession at work in these simple settings, we will be in a better position to perceive that it also operates in other contexts involving intangible rights and often operates in competition with the principle of first possession.

1. Newborn animals. Let us begin with some folksy examples that govern agrarian activities. Under the doctrine of increase, " $\mathrm{t}]$ he general rule, in the absence of an agreement to the contrary, is that the offspring or increase of tame or domestic animals belongs to the owner of the dam or mother" (Carruth v. Easterling, 150 So.2d 852 (Miss. 1963)). Here we have a striking example of a new resource-the newborn animal-that enters the world.

4 A much-cited article (Arnold) reflects this narrowing of the use of the term accession. Arnold treated the Roman law doctrines of specificatio (transformation of personal property by the labor of another) and accessio (joinder of personal property of two persons into a single item) as two variations on a single doctrine, which he called accession. He also distinguished confusion as a separate doctrine from what he called accession and put aside other doctrines like increase, fixtures, and accretion, "which in the Roman law, came within the broadest meaning of the accession" (Arnold, 104). By 1936, when the leading modern treatise on personal property was written, a similar classificatory scheme was followed (Brown 1936). Brown too used the word accession to cover both specificatio and accessio, distinguished accession and confusion, and treated other doctrines like fixtures and emblements as unrelated (Brown, 1936 at 46-74; $627-89 ; 690-704)$.

5 See UCC 9-335 (rule of priority for security interests in "accessions"); id. 9-336 (rule of priority for security interests in "commingled goods"); see also UCC 9-315(b) (secured party's rights on disposition of commingled goods). The UCC basically inverts the common law concepts, defining an accession as a physical uniting of goods such that the identity of the original goods is not lost. See UCC 9-102. What the common law regarded as an accession-the uniting of goods so that their identities were lost-the UCC describes as a case of "commingled goods." Needless to say, this kind of terminological revisionism does little to encourage inquiry into historical principles (see Frish). 
Conceivably, ownership of this new resource could be assigned to its first possessor. Instead, ownership of newborn animals is uniformly assigned to the person who owns another resource that has a prominent connection to the new resource-the newborn's mother. Notice that prominent connection in this instance is biological rather than physical, although presumably in most cases maternal biological connection will translate into physical proximity. Felix Cohen once reported that all known legal systems follow the rule of increase (Cohen, 366). ${ }^{6}$

2. Crops. When we turn from animals to plants, similar rules apply. Socalled fructus naturales-trees, bushes, and other perennials and their fruits-are always regarded as belonging to the owner of the soil. Thus, provided the land is privately owned, even the Lockean exercise of gathering acorns from the forest is actually governed by the principle of accession rather than first possession. The rules that apply to fructus industriales-annual crops that require planting and cultivation-are slightly different. Here, too, the baseline rule is that growing crops belong to the owner of the soil. Thus, for example, a sale of a farm is presumed to include the rights to growing crops, absent a reservation to the contrary (Brown 1955, 818). Sometimes the identity of the person in possession of the soil changes between the planting and harvesting of the crops, for example, when a life tenant dies or a tenant at will is terminated. When this happens, under the doctrine of emblements, the crops belong to the person in possession of the soil when the crops were planted. This interesting wrinkle presumably protects good faith cultivators from being denied the fruits of their labors. Nevertheless, the doctrine of emblements can also be seen as a species of the principle of accession, insofar as the person in possession at the planting (and afterwards) can be said to have a more prominent connection to the crops than the person who does the harvesting. ${ }^{7}$

3. Accretion. Another traditional application of the principle of accession is the doctrine of accretion. This provides that a riparian landowner whose land is gradually augmented by alluvial formations owns the newly formed land (see, e.g., Nebraska v. Iowa, 143 U.S. 359 (1892)). In theory, we could

6 The rule was subject to an exception in English common law for baby swans or cygnets, which were divided equally between the owner of the cock and the owner of the hen (The Case of Swans, [1592] 77 Eng. Rep. 435). The court opined that this was because of the strict monogamy of swan cocks, in marked contrast to "kine or other brute beasts" (at 437), which presumably eliminated any dispute about paternity.

7 Both fructus rules, like the doctrine of increase, are defaults; the individual who is designated the owner under the accession rule can designate by contract some other person as owner. But this feature is true of most property rules, which assume alienability of the right. 
declare that the new soil belongs to the first possessor or to the state to distribute as it sees fit. But no known legal system, going back to Roman times, follows such an approach. Instead, the new soil always goes to the riparian owner on whose banks the new land is attached, who readily can be said to have the most prominent relationship to it. ${ }^{8}$

4. Commingled goods. Sometimes goods are "physically united with other goods in such a manner that their identity is lost in a product or mass" (see U.C.C. $\$ 9-336(a))$. This creates a problem in identifying the owner of the resulting object. The Romans applied three doctrines here: accessio, specificatio, and confusio (Slater). Accessio applied when two different items were joined together in a production process, as when A supplied flour that was put into sacks owned by B. Specificatio applied when A owned raw material that was transformed by B's labor into a different product, like lumber milled into barrel hoops. Confusio applied when two or more persons provided similar inputs that were mixed together in such a way that their contributions could not be distinguished, as when grain from two or more farmers was combined in single container. American courts today tend to use the word accession to cover both accessio and specificatio and then distinguish accession from confusion (confusio). ${ }^{9}$ Notwithstanding the verbal peregrinations, the basic principle in all areas reflects a straightforward application of the principle of accession. The question in each case is which owner of inputs has supplied the larger or more valuable input-i.e., has established the most prominent connection (Shaham and Sher). Variations emerge with respect to whether the person who supplies the less valuable input is entitled to compensation. ${ }^{10}$ But as to the basic question of ownership, the principle of accession prevails.

8 In contrast, when a river or another body of water suddenly changes its course, the boundaries remain the same under the principle of avulsion. A possible explanation might be that with avulsion, as opposed to accretion, there is a clear loser as well as a winner. The intuition may be that it would be too destabilizing to the system of property rights to declare that a freak event of nature can divest property from $\mathrm{A}$ and transfer it to $\mathrm{B}$.

9 See note 3.

10 What the Romans called specificatio presents the most interesting qualifications, perhaps because recognizing a general right of compensation for unsolicited services would create an obvious moral hazard. We do not want to have to pay the laundry for shirt monogramming we did not order. Thus, most courts do not award the object to the laborer, even if the labor is the larger or more valuable input, unless the laborer acted in good faith-i.e. without actual knowledge of the superior claim of the owner of the object (Wetherbee v. Green, 22 Mich. 311 (1871)). Also, if the laborer is found to have made the smaller or less valuable input, the laborer generally has no right of action for restitution for the value of the labor services. In contrast, if the supplier of the physical input is determined to provide the smaller or less valuable input, this person can sue the laborer (who is awarded the object) for conversion damages. 
5. Ad coelum. Although not generally recognized as an example of accession, the ad coelum doctrine, ${ }^{11}$ which declares that the owner of the surface of land owns from the depths to the sky, is in fact one of the most important incarnations of the principle. Justice Douglas once declared that this doctrine "has no place in the modern world" (United States $v$. Causby, 328 U.S. 256, 261 (1942)). In fact, the doctrine is fundamental to property rights in land. Deeds to land are nearly always stated in terms of some measurement of the surface area. Because of the ad coelum rule, the owner of the surface is also entitled to dig below the surface (for example, to construct a basement for a building) and to build above the surface (to build the building itself). As applied in American law, the ad coelum rule also means that, absent a severance, the owner of the surface owns any minerals discovered below the surface and any caves discovered beneath the surface and has the right to extract groundwater and oil and gas from beneath the surface.

It is relatively easy to see that the ad coelum rule is yet another application of the principle of accession. We start with ownership of the surface. Then, as new increments in value are discovered beneath the surface (minerals, caves, groundwater) or above the surface (capacities to exploit air rights), these increments in value are automatically assigned to the owner of the surface-the most prominent preassigned property right. Not surprisingly, the rule can be found in Roman sources and is apparently followed in all civil and common law jurisdictions (Carroll).

6. Fixtures. Another application of considerable ongoing significance is the doctrine of fixtures. A fixture is "a thing which, although originally a movable chattel, is by reason of its annexation to, or association in use with land, regarded as part of the land" (Brown, 1955, 698). The case law is voluminous, and several factors play a role in determining whether a chattel is a fixture: physical attachment to the realty, appropriation to the use or purpose of the realty, and common understandings are all said to be relevant (Squillante; van Vliet). But the basic inquiry is similar to what we see under the principle of accession more generally, asking whether the chattel bears a relationship to the land that is so physically close or otherwise prominent that the chattel should be regarded as being owned by the owner of the land.

11 Short for cjus est solum, ejus est usque ad coelum et ad inferos. This has been translated as "to whomever the soil belongs, he owns also to the sky and the depths." 


\section{B. Intangible Rights}

We can also find examples of the principle of accession at work with respect to intangible property, although the term accession is rarely encountered in this context.

1. Interest. Consider the question of who owns the interest earned on a fund of money that has been deposited in an interest-bearing account. Ordinarily, of course, the matter will be governed by contract; the owner of the fund will enter into a contract with the depository institution that specifies what happens to the interest. But under some circumstances involving escrow funds, security deposits, or prepayments for services, there might be no contract or the government might mandate that interest be paid as a matter of law. As discussed by the Supreme Court in no less than three modern decisions, the common law rule here is that interest follows principal (Brown v. Legal Found. of Washington, 538 U.S. 216, 235 (2003); Philips v. Washington Legal Found, 524 U.S. 156, 164-71 (1998); Webb's Fabulous Pharmacies v. Beckwith, 449 U.S. 155, 162-64 (1980)). In other words, the interest is understood to belong to the owner of another resource prominently connected with the interest - the principal on which the interest was earned. This rule is so firmly entrenched that the Court has (perhaps unwisely) given it a constitutional dimension which appears to be impervious to legislative modification.

2. Adaptation rights. The principle of accession also plays a large role in intellectual property regimes. Copyright provides a particularly striking illustration. The Copyright Act confers on the holder of a copyright not only the exclusive right to copy the work, but also the exclusive right to prepare derivative works based on the work, known as adaptation rights (17 U.S.C. $\$ 106(2)$ ). For example, the author of a copyrighted book has the exclusive right to prepare a screenplay for a movie based on the book. Here we see a clear instance of the holder of the more prominent property-the original book-being also given the right to control lesser (meaning here less original) variations on this right (Abramowicz, 2005).

3. Patent improvements. Patent law is also very accession-like in its treatment of improvements. As Edmund Kitch has explained, patents typically claim an invention that "works" but is not necessarily one that is commercially viable (Kitch 275-80). After the patent is granted, the patentee is given the exclusive right to tinker with and refine the invention, to see whether it can be made into something commercially viable. These further improvements, even if they are themselves not sufficiently original to 
warrant patent protection, also belong to the patentee-by accession as it were-because the patentee can block anyone else from using an invention that incorporates the patent. The doctrine of equivalents, which extends protection beyond the literal claims of the patent to include in addition anything that differs in modest ways from the claims, even more clearly incorporates the idea of accession (Merges and Nelson 865-66; Lemley 1997, 1070).

4. Trademark Dilution. Trademark law has come to reflect the principle of accession, through the protection against dilution of famous marks. Originally, trademark protection attached only to particular distinctive marks used in connection with particular goods and services. The system operated on the basis of first possession, as the first firm to "capture" consumer recognition of its mark in a particular market was awarded an exclusive right to use the mark in that market. As brand management became increasingly important, however, firms sought and obtained from Congress a broader form of protection against dilution of famous marks (see 15 U.S.C. $\$ 1125(\mathrm{c})$ ). This new protection has the effect of extending the scope of trademark protection beyond commercial uses actually captured to uses not captured but which have a close enough connection to a famous mark to do it potential harm (Long, 1034). In other words, famous marks are now recognized as having an accession-like power over any use of the mark having a close enough connection to the mark to affect its value as a mark.

5. Publicity. A final example from the realm of intellectual property, the right of publicity, can be thought of as nothing more than a bundle of accession rights. The right applies to celebrities who have a persona that has commercial value (Grady, 103). The celebrity herself is obviously in control of ("owns" or is in "possession" of) her persona. The right of publicity permits the celebrity (or in some states, her estate) to determine which, if any, commercial markets she wishes to enter to reap a commercial gain from her persona. Thus, Bette Midler can decide whether the sound of her voice can be used to help sell Fords on television (Midler v. Ford Motor Co., 849 F.2d 460 (9th Cir. 1988)), Arnold Schwarzenegger can decide whether his image can be used in a line of bobblehead dolls (Broder), and so forth. In each case, we can say that the secondary right-to use the image of the celebrity in a particular commercial market - is assigned by accession to the owner of the primary right - the right of the celebrity to control the persona itself. 


\section{Contested Issues}

Now that we have seen a variety of examples of the principle of accession at work, it is illuminating to consider some situations in which the law is uncertain about whether ownership of contested resources should be assigned by first possession or accession. Most of these situations involve fairly low-valued resources or issues that arise too infrequently to generate any iron-clad conclusions. Nevertheless, we see an unmistakable pull toward accession in these cases, particularly as the background condition becomes thicker with established property rights or as economic values become greater.

1. Wild animals. Ownership of wild animals is one ground of contestation. Although American students are taught that first possession prevails here, there is in fact a competing principle-sometimes called ratione soli (by reason of the soil)-that awards rights to wild animals to the owner of the land on which they are killed or captured. England, with its large landed estates, was traditionally more receptive to this competing principle than America (Lueck, 1989). In the United States, a privilege of hunting on any unenclosed land was recognized early in many states (Goble and Freyfogle, 133-140). But even in America, rights to certain wild animals, such as bees, have always been assigned to landowners rather than first possessors (see State v. Repp, 73 N.W. 829 (Ia. 1898)). Other wild animals that build homes in fixed locations, such as beavers and muskrats, as well as shellfish that grow in beds in fixed locations, are also more likely to fall under the principle of ratione soli, which is to say, accession.

Even with respect to traditional animals, ferae naturae, American law over time has moved substantially toward accession. A rule of open access has given way to rules permitting landowners to exclude hunters either as a matter or law or by posting no hunting signs (Signon). As rural areas have become more settled, exclusion has come to dominate over open access. Access to wild animals today increasingly requires the permission of the owner of the soil, with the result that the principle of accession has in effect come to prevail rather than pure first possession. ${ }^{12}$

12 To be clear, the owner of the soil does not own any wild animals until they are captured on the land. The same is true of oil and gas and groundwater. Ownership of the land gives the surface owner an exclusive option to capture or to license others to capture fugitive resources on or under the land, but the fugitive resource must still be reduced to possession (by someone) before ownership attaches. 
2. Finders. Lost property provides another area of contestation. When a lost item is found, disputes often arise as to whether the found object belongs (in a qualified sense-the rights here are subordinate to the claims of the true owner) to the individual who makes the find or the owner of the locus in quo. This is another straightforward contest between first possession and accession. Courts have had little trouble ruling for the owner of the locus in quo when the finder is trespassing or the item is attached to or buried beneath the soil (e.g., Favorite v. Miller, 407 A.2d 974 (Conn. 1978); Barker v. Bates, 30 Mass. 255 (1832)). ${ }^{13}$ The latter line of cases is reminiscent of the doctrine of fixtures and reveals again how the claim of the landowner takes on more gravitational force as connectedness with the soil becomes more pronounced.

American courts have pushed further in the direction of ruling for landowners in finders cases by applying the doctrine of mislaid property (see Benjamin v. Lindner Aviation, Inc., 534 N.W. 2d 400 (Ia. 1995)). Items are mislaid when you deliberately put them down someplace and then forget them. Mislaid property always goes to the owner of the locus in quo. Because a significant portion of lost property can be characterized as mislaid, this doctrine moves a large number of cases from the first possession category over into the accession column.

3. Meterorites. Cases involving falling meteorites can also entail a competition between the person who finds the meteorite and the owner of the land on which it falls. As a rule, the landowner wins, especially when the meteorite is buried in the soil (Goddard v. Winchell, 52 N.W. 1124 (Ia. 1892)). In 1954, in Sylacauga, Alabama, a meteorite crashed through the roof of a house; bounced off a radio sitting on a table; and struck the tenant, Ann E. Hodges, bruising her arm and hip. Litigation ensued between the landlord and the tenant over who had the better claim to the meteorite. Although the landlord claimed title as owner of the soil, the tenant claimed a special equity based on the fact that the meteorite struck her. Eventually, the landlord settled on terms permitting Hodges to retain possession (Merrill and Smith, 2007, 233-34). Although this could be construed as a preference for the first possessor (if being struck qualifies as possession), it can also be viewed as a dispute over which of two persons with an interest in the locus in quo had a better claim to accession.

13 Some jurisdictions treat embedded items as a separate category, justifying an award to the landowner (Gerstenblith, 591-92). 
4. Street parking. If hunting is important to rural residents, then parking is a matter of first magnitude for urban residents. Parking on public streets is generally allocated on the basis of first possession, and this remains the dominant rule (Epstein 2002). Nevertheless, as urban parking space becomes increasingly scarce, cities are turning to systems in which only cars displaying permits are allowed to park on the street. These permits are nearly always allocated to those who own or occupy property on the street in question. In other words, the right to park is given by accession to those who live or work on the street. These permit systems reveal how conditions of general scarcity can cause a system of allocation based on first possession to be replaced by one based on the principle of accession.

5. Domain names. A final, and particularly instructive, example concerns the assignment of domain names on the Internet. With regard to the Internet, in the beginning all the world was indeed America. That is, the background condition was widely regarded as one vast cyberspace, in which rights to things like domain names would be assigned by first possession. At first, the allocation followed the first possession script, as the initial contractor responsible for issuing domain names, Network Solutions, Inc. (NSI), simply issued names on a first-come, first-served basis. Soon wily characters began acquiring domain names that corresponded to trademarks or trade names of established entities which had been slow to recognize the value of the Internet. Some of these first possessors offered to sell the laggard entities the rights to use their own trade names on the Internet, a practice known as cybersquatting.

A number of these entities elected to sue, claiming that the practice of cybersquatting constitutes either trademark infringement or trademark dilution. The courts agreed, holding that owners of property rights established in traditional commercial channels_-trademarks-could extend those rights to the new environment of the Internet, notwithstanding the formal adoption of a rule of first possession as the mode of assignment of names for that new environment (see, e.g., People for the Ethical Treatment of Animals v. Doughney, 263 F.3d 359 (4th Cir. 2001); TCPIP Holding Co., Inc., v. Haar Communications, Inc., 244 F.3d 88 (2d Cir. 2001)). Congress quickly ratified this result by enacting the Anti-Cybersquatting Consumer Protection Act (15 U.S.C. $\$ 1125(\mathrm{~d})$ ). It is now well-established that principles of trademark law trump the first-come, first-served registration rules of the Internet. This is a dramatic example of the principle of accession superseding first possession. It suggests that when the economic 
stakes are sufficiently high, accession can replace first possession in fairly short order.

\section{The Ubiquity of Accession}

Many of the instantiations of the principle of accession we have canvassed have been ignored by property scholars, apparently on the grounds that they are too quaint, quirky, or inconsequential to warrant our attention. And there has been no discussion of the possibility that they might reflect a more general principle of property law. Yet after we state the principle at a sufficient level of generality, we can see applications of accession popping up throughout the law. This in turn suggests that the specific instantiations I have reviewed are simply the tip of the iceberg of a much more general phenomenon about property rights-one so pervasive and general that it escapes our everyday notice.

Generalizing further, we can see that the principle of accession works all the time to allocate new resources and increments in value to particular owners of property. Suppose A owns a large tank of oil and world oil prices skyrocket. No one questions that A also "owns" the windfall reflected in the enhanced value of the oil in the tank. The relationship is so prominent that accession is applied without thinking about it. Or suppose B owns a hardscrabble farm and a nearby city grows to the point where the farm is suddenly valuable for subdivision. No one doubts that B "owns" the windfall gain in terms of the development value of the farm. Again, the relationship is so prominent it goes without question. When the connection between some new value and existing property is close, we automatically assign the new value to the connected property without giving it any thought. The various doctrines in the accession family come into play only when there is enough separation between the primary and derivative asset that there is some ground for contestation about how rights to the derivative asset should be allocated.

The basic point is that property law includes as a central design feature the owner's routine capture of all increments in value that are prominently connected with the owned asset. With respect to most increments in value, most of the time, this design feature operates silently and without controversy. Only when a new increment in value has a somewhat attenuated connection with the asset, or when the new increment in value takes a form that allows us to think of it as a separate asset, do we turn to one of the family of doctrines that comprise the principle of accession to establish 
whether the owner of the primary asset also owns the derivative asset. In this respect, the principle of accession is visible mostly in unusual cases, but consideration of the operation and function of the principle allows us to see that it is really quite ordinary_-and fundamental.

\section{FIRST POSSESSION AND ACESSION: COMMON FEATURES}

In this Part, I consider briefly how first possession and accession complement each other in establishing a system of property rights. Both principles operate to identify unique persons as owners of particular resources. Moreover, both principles perform this function in a way that imposes minimal informational demands on members of society. These shared features create the conditions that permit free alienation of resources, so that scarce things can be assigned and reassigned until they end up in the hands of those who can extract the most value from them.

\section{A. Conceptual Connections}

Notwithstanding the differences between first possession and accession, they also share certain important attributes. Both can be seen as particular conceptions of a more generic concept of possession. The concept of possession relates to the idea of being in control of some thing. First possession can be said to select out circumstances where some person is sufficiently close to being in control of a previously unowned thing as to be "in possession" of it. Accession can be said to select out the circumstances where some existing property owner is sufficiently capable of controlling a previously unowned thing as to be "in possession" of it. In both contexts, declaring someone to be "in possession" is closer to saying that she has an exclusive right to control some thing than to saying she is in fact in control of the thing.

One can also argue that first possession and accession presuppose each other. Accession works only when other property rights already exist. Accession therefore cannot explain how the first property rights come into being. If we start with a condition in which most resources are unowned, then arguably the first stage in establishing ownership will be dominated by something like first possession, and only after significant ownership has been established can we switch, in a second stage, to something like accession. 
Yet if accession requires first possession, first possession can be said to presuppose a version of accession. This is because first possession is also based on a prominent connection between two resources-namely, the connection between the labor or other exertions of the first possessor and the thing reduced to possession (Smith, 2007, 1766-77). Locke's theory of the original ownership, for example, uses accession-like language in explaining why mixing labor with objects initially held in common produces ownership (Locke 287-302). Locke assumes that the labor is an asset that is "owned" by the first possessor and that the "labour makes the far greatest part of the value of things" reduced to possession (id. 297). This sounds like accession: awarding ownership to the contested resource based on its prominent connection to some already-owned resource. In the Lockean account of the origins of property, therefore, we can say that accession operates at the first stage in establishing ownership, and first possession comes in at a second stage.

None of this is to suggest that first possession and accession are the same thing. As discussed in Part III, there are important institutional differences between first possession and accession. Still, they have a significant degree of conceptual affinity.

\section{B. Unique Assignment}

First possession is often praised as a mechanism for transferring resources from an open access state into private property rights. As Richard Epstein has written (Epstein 1987, 415): "With respect to land and chattels, there is no obvious assignment of any external things to any particular individual. In this context the first possession rule at common law allows persons to come forward and become single owners of external things." The virtue of first possession, on these accounts, is the virtue of private property more generally. First possession is a beneficial institution because it establishes particular persons as the exclusive owners of particular things ( $c f$. Heller).

As should be clear, however, first possession holds no advantage over accession in this regard. Accession also transforms resources that are unowned or are of doubtful ownership into private property. Moreover, like first possession, accession assigns ownership uniquely, in a winner-takeall fashion. Accession follows a different logic in identifying the singular owner. Under first possession, the race for each resource is assumed to have a single winner. Either Pierson or Post gets the fox; they are not awarded 
title as tenants in common. ${ }^{14}$ But accession also assigns rights to contested resources in a winner-take-all fashion. Prominent connection is an ordinal concept, such that one thing is (nearly) always more prominently connected to some other thing than is any other thing. In the usual case, we can tell as soon as a new or an unclaimed resource emerges which existing asset has the most prominent connection to the new resource. Thus prominent connection, like first possession, has the capacity to generate unique solutions to the question who is the owner.

In short, insofar as it is socially beneficial to have a mechanism for assigning unique gatekeeper-owners to particular resources, there is no basis for preferring first possession to accession, or vice versa, in terms of the ultimate results they achieve. Both distribute scarce or otherwise valuable resources in a one-person-one-resource fashion, thereby creating a system of decentralized gatekeeper rights that is the hallmark of property.

\section{Information Costs}

A system for establishing property rights must do more than identify unique owners of particular resources. It must also do this in a way that imposes only a modest informational burden on the members of society. As Henry Smith and I have stressed in a variety of writings, the nature of property as an institution makes information costs critical (Merrill and Smith, 2000; Merrill and Smith 2001). Property rights are rights in particular things that are held against "all the world"; they are in rem. This feature of property places potentially enormous informational demands on society. Property rights create duties of abstention that must be observed by a large number of unconnected persons, many of whom are legally unsophisticated. If these duties of abstention required the application of subtle distinctions, extensive fact finding, and frequent recourse to adjudication, property rights would never get off the ground. If we are to have property at all, the basic concepts must be ones that a third-grader can grasp with little conscious reflection-concepts like "keep off!" and "don't take!"

In this institutional setting, the rules for establishing original ownership of things must also be simple, intuitive, and easy to grasp. Such rules

14 Academic commentators are more sympathetic to splitting entitlements (see, e.g., Helmholz; Rubenfeld). Dale Mortensen has used game theory to show that splitting entitlements among contestants generally results in suboptimal search effort (Mortensen). But he also concurs in the view, to be considered momentarily, that awarding all of the entitlement to the winning contestant under a rule of first possession can result in excessive search effort (over-racing). 
must not only generate unique solutions, but they also must be capable of self-application in most cases without the intervention of state officials. They must be solutions that enjoy widespread consensus (Merrill and Smith, 2007a).

First possession satisfies these general requirements. The idea that being first to claim some thing confers an entitlement to that thing relative to all others is both intuitive and widely adopted. Queuing for taxis, volunteering in class, and taking numbers at the deli counter are familiar examples. The actions that constitute claiming vary by context and require a shared understanding of meaning between the claimant and the audience, including competitors (Rose, 1985, 82-85; Smith, 2003, 1115-22). But the concept remains easy to grasp, even if the applications vary in accordance with the customs of different resource users.

Importantly, the principle of accession-which assigns ownership based on prominent connection to existing property-also satisfies the general information cost constraints for establishing original ownership. There is usually ready agreement about what thing is most prominently connected to some other thing. Why this is so is not entirely clear. Human psychology is one possible explanation. Social convention is another.

The philosopher David Hume offered a psychological explanation for what he saw as the universal force of the principle of accession. Hume was especially fascinated by the observation that prominent connection seems always to run from great to little objects rather than the other way around. He wrote, " $[\mathrm{t}]$ he empire of Great Britain seems to draw along with it the dominion of the Orkneys, the Hebrides, the Isle of Man, and the isle of Wright; but the authority over those lesser islands does not naturally imply any title to Great Britain" (Hume, 510 n.2). As to the factors that determine which of two objects is great and which is little, Hume saw many candidates with possible appeal to the human imagination. "One part of a compound object may become more considerable than another, either because it is more constant and durable; because it is of greater value; because it is more obvious and remarkable; because it is of greater extent; or because its existence is more separate and independent" (id.). These potential defining factors, he conceded, can be "conjoin'd and oppos'd in all the different ways, and according to all the different degrees, which can be imagined" (id.).

There is almost certainly something to the idea that prominent connection is hard-wired in the psychology of human perception. One only has 
to read judicial decisions declaring that mirrors attached to the wall with screws are fixtures whereas mirrors hanging from the wall by hooks are not (see Strain v. Green, 172 P.2d 216 (Wash. 1946)), to begin thinking that there must be strong psychological forces that equate physical connectedness with ownership.

Robert Sugden has offered a neo-Humean account of how accession generates unique solutions to questions of ownership (Sugden 94). Sugden's account is embedded in a more general theory about how social conflicts are resolved by conventions developed over time that generate positive sum outcomes. One reason such conventions emerge, he suggests, is that certain solutions have a natural "prominence" that makes them focal points for coordination. Sugden illustrates the importance of prominence by describing a simple game he asked experimental subjects to play, presented in Figure 1 (id. 94).

Contestants who play this game nearly always select as the point of coordination the white dot just above and to the right of the black dot, which is closest in terms of physical proximity to the black dot. Other choices are logically possible, such as the dot directly below the black dot or the dot in the upper-right corner, which is farthest away from the black

\section{Figure 1}

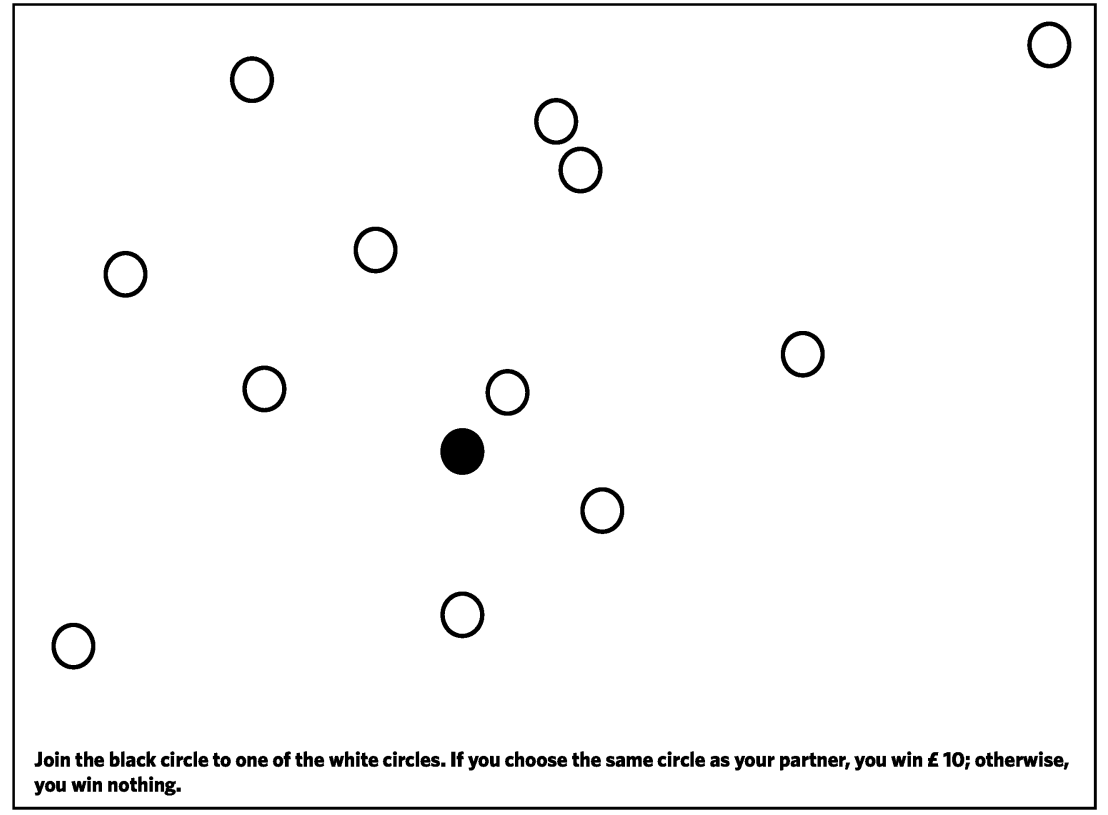


dot. But Sugden reports that these dots are rarely chosen. The explanation, of course, is that these choices have much less "prominence" than the closest dot.

Sugden grounds accession not in human psychology but in a theory of the evolution of social conventions. This includes as one of its elements functionality-the generation of stable positive sum solutions-which can account for why something like the principle of accession becomes reflected in law and why it has staying power. Sugden stresses that the evolutionary process that produces stable conventions will favor not only unique solutions, but also what he calls "cheat-proof" rules (id. 101). This he says counts "against conventions-however much we might approve of them from a moral point of view-that are subtle or subjective, or that require fine judgments" (id. 100). This too seems an apt characterization of most of the doctrines that reflect the principle of accession.

Whatever the ultimate explanation for perceptions of prominent connection, it seems clear that prominent connection allows us to assign ownership in a way that is easy to understand, is self-applying, and generates very little conflict. Accession thus functions in a manner analogous to other bright line rules of property law, such as the rules against unlicensed boundary crossings of land or asportations of chattels. These rules establish principles of resource management that are simple, intuitive, and selfapplying-and hence operate with very low information costs.

\section{FIRST POSSESSION AND ACESSION: DIFFERENTIATING FEATURES}

If accession shares important conceptual and institutional features with first possession, it also reflects important differences. Let us begin by seeking to specify these points of differentiation more precisely. After we have done that, we will be in a position to account for the widespread use of accession in establishing ownership and explain why accession seems to dominate first possession when both are potential options for resolving who owns what.

\section{A. Conceptual Distinctions}

As previously discussed, first possession and accession have a family resemblance in that both are related to the concept of possession. Yet they are also different. Two points of contrast are particularly important. 
One concerns the assumed background condition against which these concepts operate. First possession assumes that the assignment of rights occurs against a background condition largely free of existing property rights-an open access common or the public domain. The hunter stalks wild game through a dense forest; the fisher casts her line in the ocean; the inventor seeks a patentable discovery in a world in which ideas are in the public domain. True, first possession is sometimes used to regulate behavior on owned property. The assignment of seats in movie theaters or parking spaces in shopping center parking lots are examples ( $c f$. Ellickson 1991). Even here, however, it is possible to conceive of the situation as one in which an owner of property has deliberately decided to place some attribute of that property "in the public domain," in the sense that the attribute is up for grabs by various contenders (Barzel 16-32). Thus, these examples do not refute the notion that there is a close connection between the concept of first possession and the idea of open access. If anything, they confirm it.

Accession, by contrast, assumes a background condition populated by existing property rights. The commons of first possession disappears and is replaced by a background in which most things of value have already been assigned to some owner. When new resources are discovered or new increments in value emerge, we look around to see which existing property owner is the most logical one (the most "prominently connected" one) to whom to assign the new resource or value.

A second significant point of differentiation is that first possession requires the performance of some act to establish ownership-the act deemed to establish possession. This ordinarily means that some actual exploitation of the resource must have occurred before ownership attaches. The fish must be pulled from the sea, the wild animal must be killed or captured, the novel expression must be embodied in a tangible medium, and so forth. Actual possession or control might not be strictly required in all circumstances. Sometimes hot pursuit or the equivalent is sufficient to establish first possession (Pierson v. Post, 3 Cai. R. 175 (N.Y. Sup Ct. 1805)).$^{15}$ Still, one must engage in the act of hot pursuit, and only after this has been accomplished is ownership established.

15 One modern salvage case permits first possession to be established by videotaping the sunken vessel (Columbus-America Discovery Group, Inc. v. Atlantic Mutual Ins. Co., 974 F.2d 450 (4th Cir. 1992)). 
Accession, by contrast, awards ownership based on status-the status of owning something prominently connected to the disputed object. There is no need to engage in any performative act that demonstrates one is in possession of the object; ownership follows automatically based on the status of being an existing owner. To be sure, prominent connection can plausibly be regarded as a proxy for capability to possess or exercise control over the contested resource. In this sense, accession can be said to select out the circumstances that allow us to assign some thing to the owner of some other thing who has the strongest claim to be able to control the thing, and hence to be "in possession" of it. But the fact remains that under accession actual possession is not required; nor is actual exploitation of the resource required. ${ }^{16}$

One could go further and maintain that accession is not a principle about the initial acquisition of property rights so much as a principle about the scope of property rights already acquired. Many accession rights, especially those associated with land, seem to clarify what is it that the owner has the right to exclude others from. For example, accession tells us that the owner of land can also exclude others from interfering with crops, fixtures attached to the land, minerals discovered under the surface, and so forth. Similarly, many accession rights in intellectual property can be seen as clarification of the scope of the rights conferred. Accession tells us that a copyright owner can exclude others not only from copying the work, but also from preparing a derivative work based on the copyrighted work, and that a trademark owner can exclude others not only from using a trademark, but also from takings action that would dilute the value of the trademark.

I would resist this characterization of accession. Accession often applies to determine the ownership of objects that are most naturally regarded as being separate or distinct from the thing that supplies the basis for accession, such as baby animals, minerals underground, or screenplays for movies. Nevertheless, even if we assume accession is about the scope of rights, it still functions as a means of establishing original title to the objects to which it applies. The title to certain things-baby animals, crops, minerals,

16 One might think that the doctrine the Romans called specificatio is an exception to this generalization, in that title is awarded based on labor, which is a type of action. But the labor required is not for purposes of establishing actual possession of the thing. If the laborer has supplied the greater value and has significantly transformed the object, the laborer will be awarded title to the object by accession-regardless of whether the laborer is in possession of the thing. The labor required is for the purpose of establishing the status of prominent connection, not for demonstrating actual possession. 
interest earned on a fund, derivative works, and so forth-finds its root in accession, whether we think of this as a principle of original ownership or a principle about the scope of property rights. The question of proper characterization here does not appear to make any difference in terms of institutional analysis. The two points of distinction I have emphasized-the assumption about the background condition of rights and whether the assignment is based on act or status-remain fully relevant to that evaluation without regard to how we characterize the distinction.

\section{B. The Pathologies of First Possession}

Although economists and lawyers influenced by economics have applauded first possession for transforming unowned resources into private property, they have had many harsh things to say about the manner in which first possession accomplishes this task (e.g., Haddock 791). The critique of first possession can be pieced together from two types of commentary. One deals with traditional natural resources problems: fisheries, grazing commons, homesteading, and the like. The other deals with intellectual property rights, where exclusion rights are conceived as being carved out of a public domain in which access is open and unlimited. Taken together, these sources suggest that first possession suffers from four pathologies: (1) wasteful consumption of resources through competition for the prize of ownership; (2) premature exploitation or overconsumption of resources (the "tragedy of the commons"); (3) inadequate incentives to cultivate or improve resources; and (4) unfavorable conditions for securing agreements for collective governance of resources. Assigning original ownership based on accession largely eliminates each of these pathologies. In explaining why this is so, I will occasionally speak of the accession-creating property as the primary resource or right and the property assigned by accession as the derivative resource or right.

1. Wasteful Races. Any system that establishes a race open to all can end up wasting valuable resources. No contestant will have an incentive to spend more on the race than the value of the prize. But each contestant might have an incentive to outspend the other contestants, provided the additional expenditures can make the difference between winning and losing. In the limit, each contestant can spend up to the value of the prize in an effort to out-compete the others. If there are multiple contestants, the expenditures incurred by the losers are a deadweight loss. Under the right conditions, the race may end up consuming more resources than it 
produces, making it a negative proposition from the perspective of social efficiency. This analysis has been applied to land races, patent races, and the quest for prizes and economic rents more generally (Anderson and Hill 1990; Barzel 1968; Grady and Alexander; Tullock).

Using accession rather than first possession to assign original ownership largely eliminates the waste inherent in racing to secure resource ownership. Under accession, the prize in the form of the derivative resource is awarded to the owner of the primary resource. Provided only one claimant satisfies the conditions for accession, there will be no rent-dissipating race (Abramowicz; Grady). Of course, in some cases disputes might arise over the identity of the primary resource or who is the owner of the primary resource. But on the whole, the potential for rent-dissipating competition among rival claimants should be greatly reduced under accession relative to first possession.

Dean Lueck's work on the economics of first possession effectively confirms this point (Lueck 1995). One of Lueck's principal findings is that the degree of waste associated with first possession is a function of the extent to which competitors are homogeneous or heterogeneous in terms of their ability to secure the prize. The more heterogeneous the competitors, the more likely that one will win the race quickly and limit the degree of wasteful racing engaged in by the others. He writes, "In the extreme case, where just one person has costs less than the net present value of the asset's flows, the first-best outcome is achieved. In this case, only one person finds it worthwhile to enter the race, so there is no dissipation" (id. 400). This essentially describes the situation achieved by switching to a rule of accession. Under accession, only one person is uniquely situated to "race" for the new asset. This is not because this person has a unique cost advantage relative to other competitors (although this might also be true), but rather because the legal rule grants him an exclusive right to acquire the asset. The result is the same: the wasteful dissipation associated with first possession is eliminated.

2. Commons Tragedies. As we have seen, first possession presupposes a background condition in which resources are held in an open access commons. Depending on the nature of the resource, this gives rise to a danger of premature exploitation or overconsumption which goes by the familiar moniker "the tragedy of the commons" (Hardin; Fennell). The tragedy can occur because the open access status creates a pervasive problem of cost externalization. Suppose 100 fishing boats are plying a bay. If boat A succeeds 
in catching a fish, the benefits of the catch are fully internalized to boat A. But the costs of the catch, in terms of foregone opportunities to catch fish, are spread over all 100 boats in the bay. So boat A incurs only 1/100 of the opportunity costs of the capture, and the other $99 / 100$ of those costs is externalized to the other boats. From the perspective of each of the boats, the calculus is the same: benefits fully internalized and costs mostly externalized. This sets up a dynamic in which each boat has an incentive to grab as many fish as quickly as possible and overall consumption can spiral out of control. If the resource is finite and especially if it is sensitive to destruction if taken before maturity or beyond sustainable levels, the result can be complete extinction of the resource. ${ }^{17}$

Using accession to award ownership to resources largely eliminates the tragedy of the commons. Under accession, both the benefits and costs associated with consumption of the derivative resource are internalized by the owner of the primary resource (Cooter and Ulen, 131). To continue with the fishing example, suppose we assign exclusive rights to fish a portion of the bay to the owners of riparian land around the perimeter of the bay as an exclusive economic zone appurtenant to the land. These exclusive aquatic territories are then enclosed with containment barriers and dedicated to fish farming. Now, each time the riparian owner removes a fish from the containment, she realizes 100 percent of the benefits and 100 percent of the costs from this action. As a result, we would expect owners to avoid taking fish before they are fully grown and to limit their consumption of the resource to rates that ensure a sustainable yield.

3. Incentives for Cultivation. Because first possession conceives of the background condition as one of open access, any regime of first possession will also provide inadequate incentives for participants to cultivate, improve, or otherwise invest in the underlying pool from which resources are drawn (Demsetz; Bohn and Deacon). Analytically speaking, this point is the same as the last one, except that the emphasis is now on disincentives to provide external benefits rather than incentives to impose external costs. Potential competitors for resources drawn from an open access commons have little incentive to stock the commons or otherwise cultivate or replenish it because all other competitors for the assets in the pool will likewise capture these benefits. For example, no individual fisher has much

17 There is ample empirical evidence that the problem is a serious one, certainly with respect to fisheries (UN Food and Ag. Org.; Wyman). 
incentive to build a fish hatchery to replenish the stock of fish in an open access fishery; all the other fishers in the area will also be able to capture the new supply of fish.

Accession solves this problem by assigning ownership of the derivative resource to the owner of the primary resource, thereby ensuring that the owner of the primary resource will capture all benefits created by investment in the primary resource. ${ }^{18}$ We see this quite literally in a number of accession doctrines, including increase; the crop rules; specificatio, the rule that interest follows principal; the adaptation right in copyright; and so forth. In each instance, the rule ensures that the owner of the primary resource will be able to "reap where he has sown" by also claiming ownership over the derivative resource.

The point can be further illustrated by Kitch's prospect theory of patents. Patents have long been conceived of as prizes awarded to the first person to capture a particular useful and original idea. Kitch asked in effect: Why is the prize awarded in the form of an exclusive property right to the invention, rather than a cash reward or an honorific? His answer was that the property right gives the inventor the incentive to invest further in development of the invention: to make further improvements in it, to negotiate with other patent holders for complementary rights, to establish a system of distribution, and to bring the invention to the attention of the public. In other words, by giving the patent holder (the primary resource owner) an exclusive right to derivative resources (improvements secured by contracting and other commercialization efforts), the law allows the inventor to make additional investments that will enhance the value of the invention, knowing that he will be able to internalize any and all benefits that flow from these additional investments. This is the logic of accession. ${ }^{19}$

4. Governance Costs. A final criticism leveled against first possession is that it increases the costs of contracting among the respective claimants to achieve any type of mutually advantageous forbearance or other collective action. This criticism again flows from the open access nature of the background condition that first possession takes as a given. Bob Ellickson has

18 Empirical studies show that privately owned oyster beds have higher productivity than open access oyster beds (De Alessi 98-99).

19 Mark Lemley derides this rationale for intellectual property as "ex post," which he says is "antimarket" (Lemley, 2004). But this critique would seem to apply equally to private ownership of agricultural land, insofar as it is justified by the incentive structure it creates to cultivate, harvest, and market crops. It is odd to characterize incentive effects as "ex post" or "anti-market." 
made the point by describing the advantages of parcelization for managing land (Ellickson 1993, 1322-35). In an open access regime, even a "small event" like growing a tomato plant is difficult to regulate because it is necessary to secure the agreement of all other participants to forbear from taking or trampling the plant. Similarly, a "medium event" like building a small dam will be nearly impossible to accomplish, given the need to secure unanimous consent not to interfere with the dam or appropriate its value. Both types of action can be achieved much more easily if the commons is parcelized and each participant is given exclusive rights over a single parcel. In the case of the small event, no contractual agreement is required at all. A single owner-gatekeeper can decide to grow and tend the plant without needing the cooperation of anyone else. With respect to the medium event, contracting is now more feasible because only a small number of individual owners are affected by the project. If their consent can be secured, the project can go forward. Only when we turn to "large events," like widespread air pollution, do we find little ground for preferring parcelization to open access because both seem to present difficult problems for collective governance.

Here again, we can see that accession, in a fashion analogous to parcelization, reduces transaction costs and hence makes collective decisionmaking easier to achieve. Accession, like parcelization, assigns particular resources (new or derivative ones) to the owner of other resources (existing primary ones). This too has the effect of assigning particular resources to specific owner-gatekeepers and is inexpensive and (usually) unambiguous. When accession operates to determine ownership of derivative resources, governance can be achieved for most issues_-Ellickson's small and medium events-by delegation or contract among the affected parties.

5. What about Lotteries or Auctions? The foregoing advantages of accession are attributable to the two differentiating features of accession described in subpart A-namely, that accession does not assume a background condition of open access and awards ownership based on status rather than the performance of some act. In theory, there is no reason the relevant status must be a prominent connection to some existing property. The same cost savings relative to first possession could be obtained by adopting any strategy based on "tying" the new resource to some existing status. ${ }^{20}$ We could award new resources to the wealthiest person in the

20 I am indebted to Robert Cooter for pressing this point on me. 
community, we could award new resources to the poorest person in the community, or we could auction them to the highest bidder. ${ }^{21}$ Why do the various rules that make up the accession family avoid these sorts of options, favoring instead the status of having a prominent connection to some existing property?

The answer has already been anticipated in Part II: prominent connection generates unique outcomes with minimal information in a way that makes accession largely self-applying. It is difficult to see any other principle for tying new resources to status that would have these features. Awarding new resources to existing owners by lottery would likely generate extensive efforts to influence the structure of the lottery and would multiply transaction costs because winners would typically sell their rights to others who are better situated to take advantage of them. ${ }^{22}$ Auctions of new resources have been proposed in some contexts, such as patents, and have even been adopted in others, such as broadcast spectrum rights. But there is ample reason to believe that auctions entail administrative costs that dwarf those of assigning rights based on prominent connection to existing rights (Abramowicz 2007). In other words, virtually any alternative assignment principle would entail extensive collective action problems. This would inevitably raise concerns about rent-seeking and the consumption of significant resources in arguing about the design and the implementation of the alternative system. The resources gained in avoiding the pathologies of first possession would be lost, at least in part, through the costs expended in fine-tuning the mechanism for assigning original rights. ${ }^{23}$

21 Access to wildlife in early English law was limited to wealthy landowners, without regard to whether the wildlife was captured on their land (Lund). Broadcast frequencies were originally assigned by first possession, then by costly comparative hearings under a public interest standard, and today are generally awarded by auctioning them to the highest bidder (Hazlett).

22 This is suggested by the experience of the FCC in awarding cellular telephone licenses by lottery. For background and an illustration of some of the interminable disputes this generated, see Folden v. United States, 379 F.3d 1344 (Fed. Cir. 2004).

23 Blackstone speculated that the right of inheritance might have originated in accession-like thinking. He thought that inheritance was grounded in the prominent physical connection between the deceased owner and the next of kin gathered around the death bed (Blackstone Vol. 2, ${ }^{\star} 11-12$ ). Whatever the accuracy of this speculation, it suggests a simple rationale for inheritance analogous to the case for accession relative to more elaborate rules for assigning ownership of assets: Passing property upon death to the next of kin eliminates the manipulation and intrigue that would accompany other possible rules for the transmission of property upon death and thus eliminates the drain on resources that these other methods would likely entail. 
In short, if we want to capture the efficiency gains of accession relative to first possession, the low-cost method for achieving this objective is to award new resources to existing owners based on prominent connection.

\section{Selecting Fit Owners}

Another way to think about the comparison between first possession and accession is in terms of the standards they incorporate for selecting original owners. As noted in Part II, both first possession and accession assign resources to unique claimants, and they do so in a low-cost way that is largely self-applying. One virtue of these features is that private property rights are quickly established. In modern property systems, moreover, the rights established under either principle are typically freely alienable. Thus, if the original owner turns out to be someone who is not particularly wellqualified to make effective use of the resource, she can sell or give it to someone else who might be better able to exploit it.

If transaction costs were zero, this process of transfer of rights would continue until the person who can make the highest and best use of the resource becomes the owner. In reality, of course, transaction costs are always positive. Thus, all things being equal, it makes sense to have the original assignment of ownership go to someone who is likely to make effective use of the resource. This will get us off to a good start in making valuable use of the resource and will eliminate the need for at least some subsequent transfers, thus saving the costs of making these transfers. ${ }^{24}$ It is important to consider, therefore, how first possession and accession compare as methods for selecting owners of resources.

First possession and accession adopt very different strategies for selecting original owners. First possession uses a strategy of competition. Various claimants race each other to determine who will be the first to engage in the performative act that qualifies as being in possession. Competition is a tried-and-true method of determining fitness. Firms compete for business, sports teams compete for championships, and students compete for admission to elite schools. Competition is of course not an infallible guide to picking the fittest owner in any given context. Sometimes the winner is just lucky. The relationship between winning and fitness is probabilistic.

24 Coase made an analogous point about the content of nuisance law. If neighbors cannot costlessly transact to resolve a nuisance dispute, nuisance law should try to anticipate the outcome the parties would agree upon if they could transact (Coase 16-19). 
Still, it is plausible to think that competition is generally a good way to pick owners who will be fit. Over a broad range of cases, those who are the most skilled and put the most effort into the competition are more likely to win than those who are unskilled and indolent.

Accession adopts a different strategy for picking fit owners. Instead of holding a competition, ownership is awarded to someone who has already demonstrated that she has the capacity to function as the owner of some prominently connected asset. We can call this strategy for selecting owners a competence strategy. There are three reasons owners of prominently connected property are likely to be competent to serve as owners of new resources. First, if someone already owns property, we know she has some capital that can be drawn upon to develop the new resource, if only to pledge as collateral for a loan. Other potential candidates for an award of the new resource, such as the winner of a competition or someone chosen by lot, might not have access to any capital. Second, the most prominently connected owner is likely to have physical access to the resource. Other candidates for ownership, including even the richest person in the community, might not be able to develop the new resource because he is barred by intervening rights holders from gaining access to it. Third, the most prominently connected owner is likely to have specialized or local knowledge or skills relevant to developing the resource. Other claimants are less likely to have such knowledge or skills.

To illustrate these points, consider a problem confronted by a number of American cities early in their development: how to assign ownership to new land created by landfilling along the waterfront. A number of principles can be imagined, including first possession, sale by auction, and retention of ownership by the government. In New York City, however, the general practice was to give preferential rights to the owners of land immediately adjacent to these newly created "waterlots," in other words, to award the land by accession (Hartog 44-68). ${ }^{25}$ This was controversial and often denounced as a form of corruption. But it had all the advantages noted previously. By awarding the waterlot to the adjacent owner, the city ensured that the land would be controlled by someone who had access to some capital, based on his existing ownership of land. The use of accession also ensured that the waterlot would go to someone who had physical access to the land; indeed,

25 By contrast, in Chicago landfill along the lake front was largely retained as government property, due to the influence of the public trust doctrine (Kearney and Merrill). 
the adjacent owner might be the only person who had access to the waterlot by land (as opposed to by water). And the use of accession meant that the waterlot was assigned to someone who was likely to have specialized knowledge and skills relevant to developing the new land. If the adjacent land had been used as a dock or wharf (a likely scenario), the owner would know how to develop the new waterlot as a dock or wharf.

Which is the better rule for picking fit owners: first possession or accession? It all depends. The difference here between first possession and accession is analogous to that between bid and no-bid contracts. Often it makes sense to award a contract based on competitive bidding. This is especially likely to be true if the good is relatively homogenous, performance is easy to monitor, there are no critical synergies with other contracts, and time is not of the essence. Other times it makes more sense to award a contract without competitive bidding. This is likely to be true if one firm has unique qualifications, performance is difficult to monitor (making firm reputation important), there are interconnections with other contracts already in effect, and time is of the essence. Thus, it is impossible to say that one strategy is inevitably superior to the other, such that either first possession or accession should be preferred as a matter of institutional design.

The tradeoffs can be further illustrated by considering which principle is best in terms of stimulating innovation. First possession is sometimes touted by intellectual property scholars as a basis for awarding rights to followon inventions because it is thought to promote higher rates of continuing innovation (Merges and Nelson; Lemley 1997; Duffy). The argument is that first possession-awarding the rights to the follow-on improvement to the first person to discover the improvement-will bring on the spur of competition, and this will translate into greater inventive activity than giving the rights to follow-on improvements to the holder of the original patent. In contrast, these scholars worry, broad accession-like rights, such as those endorsed by Kitch's prospect theory, will have the effect of inducing complacency about innovation.

But the question of whether first possession is more of a spur to innovation than accession turns on some of the same contextual factors considered previously that are relevant in determining whether competition or competence is a better basis for determining fitness. For example, if the innovation is not closely entwined with the original invention, the stimulus of competition might be better. If the innovation is closely connected with, and requires detailed knowledge of, the original innovation, competence 
might be more important. A single answer is unlikely to be correct in all circumstances.

Merges and Nelson have developed evidence from the history of patent law that seems to suggest that awarding rights to follow-on improvements by first possession does result in a more rapid rate of technological progress than awarding rights to follow-on improvements by accession (Merges and Nelson; see also Wu). Specifically, they show that in industries in which pioneering patents have been construed broadly - and hence include many follow-on improvements-development has occurred more slowly than in industries in which pioneering patents have been construed narrowly.

But the effect Merges and Nelson measure can be due to the fact that the very breadth of the pioneering patents meant that subsequent innovations were not closely connected to the knowledge and skill that led to the development of the original innovation. This suggests an important limitation on the domain of accession. The ability of accession to select fit owners depends on the existence of a close enough connection between the primary asset and the derivative asset that the owner of the primary asset can exercise effective control over the derivative asset.

It is also important to remember, however, that accession enhances the incentive to innovate, insofar as accessionary rights make original discoveries more valuable. Thus, if inventors know that a patentable invention includes not just the invention but also the rights to improvements, the inventor will have a greater incentive to expend effort on discovering the original invention. At a minimum, the incentive boost from accession for the original inventor has to be considered as an offset to any diminished incentive due to insulation from competition.

In sum, although accession appears to be generally superior to first possession insofar as accession largely eliminates the four pathologies associated with first possession discussed in subpart B, it is likely that in some circumstances-but not all-first possession will do a better job of selecting initial owners who are fit. First possession is especially likely to do better on this score when primary rights are thin or widely disbursed and thus do not permit existing owners to exercise effective control over new or derivative rights.

\section{Administrative Costs}

It is also important to take into account the administrative costs of awarding original ownership under first possession as opposed to accession. In 
some circumstances, it is undoubtedly cheaper to establish original ownership by first possession-cheaper in the sense of consuming fewer legal resources devoted to establishing and enforcing such rights. Two variables of primary importance here are the costs of identifying the performative acts that qualify for purposes of first possession and the costs of identifying which resources are prominently connected to other resources for purposes of accession. Other things being equal, we would expect to see greater use of accession where the costs of identifying the performative acts that constitute first possession are high relative to the costs of identifying prominent connections (and vice versa).

As in the case of ability to select fit owners, it is hard to draw any conclusions about administrative costs across the board. Certainly it is not possible to say that first possession is always administratively cheaper. In some contexts, such as reeling in fish or staking claims to spots in shopping center parking lots, the administrative costs of identifying the first possessor are low. The act that constitutes taking possession is well understood and easily observed by others, and disputes almost never result in litigation. In others contexts, like staking claims to valuable minerals or awarding patents to new inventions, the administrative costs of identification are significantly higher and disputes and litigation are common.

The administrative costs of awarding ownership by accession also vary with other contextual factors. Consider the different treatments of hard rock minerals and fugacious minerals under the ad coleum rule. With hard rock minerals, the costs of determining which minerals are prominently connected with which surface rights, although not trivial, are sufficiently low to permit allocation by accession. With fugacious minerals such as oil, gas, and groundwater, however, it is prohibitively expensive to determine which minerals are prominently connected with which surface rights (Kiew). This is because changes in pressure continually cause these minerals to shift around in underground cavities, where they cannot be directly observed. Thus, fugacious minerals are generally subject to a rule of capture or first possession.

The comparison of administrative costs is also a function of the thickness of the universe of primary property rights. Suppose the contested resource is coconuts that fall off trees. If the trees are in a sparsely populated jungle with no clearly delineated land rights, then awarding the coconuts by first possession will undoubtedly be cheaper. But if the trees are in a highly 
developed suburban subdivision, accession should be cheap and easy to administer. This suggests that the administrative costs of accession, and hence the frequency with which accession is used to award original ownership, is significantly influenced by the degree of articulation of primary property rights, which in turn will be a function of the overall level of development of the economy.

Accession not only requires that the system of primary property rights be reasonably thick and well-defined, but also that they be enforced. Where a system of primary property rights has broken down, or exists only on paper, we are more likely to see recourse to first possession. In the California gold rush, for example, the federal government technically controlled nearly all the lands where valuable gold was discovered. But because the federal presence in the region was too feeble to permit enforcement of the government's claims, mining rights were quickly allocated by first possession (Libecap 29-34; Umbeck).

Overall one would predict, following Demsetz (Demsetz; Anderson and Hill), that as resource values rise, as the system of primary property rights becomes more articulated and securely enforced, and as new technologies emerge that lower the costs of identifying resources as being prominently connected to existing rights, we will see shifts from first possession to accession in a wide variety of situations. This is because accession, as we have seen, is generally superior to first possession on efficiency grounds given the many pathologies of first possession.

To sum up, in societies where property rights are reasonably thick and securely enforced, accession is generally preferred to first possession because accession avoids the inefficiencies associated with first possession-excessive racing, commons tragedies, underinvestment in common resources, and poor conditions for collective governance. The primary exceptions are circumstances in which we have strong reason to believe that first possession will do a better job of selecting fit owners (arguably the patent situation where rates of innovation are of special concern) or in which resources are fugitive or for some other reason are difficult to pin down using the concept of prominent connection. Overall, as property systems expand and mature, accession increasingly crowds out first possession as a mode of establishing original ownership. 


\section{ACCESSION AND INTERNALIZATION}

We are now in a position to understand how accession is a very general principle, integral to the basic logic of using property as a strategy for the management of resources. We can also understand how accession can help to clarify some puzzles that economists have raised about the economic organization of production.

A system of property rights can be seen as a way of organizing the management of valuable resources. The property strategy appoints a singular gatekeeper for each resource, a mini-sovereign who determines who gets included and excluded, what use will be made of the resource, and when it will be sold (Smith, 2002). The strategy works in large part because the gatekeeper internalizes the benefits and costs associated with this delegated managerial function. Decisions that expand or reduce social output, as judged by the market, inure to the benefit and detriment of the gatekeepermanager (Bentham, 110).

To ensure that routine internalization of these gains and losses occurs, we need some principle that automatically assigns all increments in value that arise over time to particular assets and their associated gatekeepermanagers. The principle of accession accomplishes this routine sweeping function. The principle of accession provides that all newly discovered resources and increments in value are allocated to the property most "prominently connected" with these new values. The principle ensures that the owner of the primary asset automatically internalizes every thing that affects the value of the asset, net of contractual obligations.

This insight is not new. It is in accord with the Roman maxim that "a man should acquire the advantages of anything to the disadvantages of which he is subject" (Grotius, 305). It seems to have been intuited by Samuel Pufendorf, the seventeenth-century German natural rights theorist, who wrote (Pufendorf 587): "[T] he possession of many things would be vain and useless, should the Fruits of them accrue to others; and the common Peace of Mankind would be very little promoted, if other Persons might challenge these improvements with the same Right and Title, as the Proprietor of the Substance to which they adhere."

The critical point is that the incentive to internalize benefits and costs we associate with property rights is created by accession. It is precisely because the owner knows that any prominently connected gains or losses will be hers, no matter what, that the owner has an incentive to manage 
the property in such a way that the gains predominate over the losses. Any other principle for assigning new resources and increments in value would dilute this incentive effect and undoubtedly divert significant resources into arguing over the proper assignment, rather than managing the primary resource itself.

We can also see how the principle of accession helps clarify what economists have come to call residual claimancy (Alchian and Demsetz; Jensen and Meckling). This refers to the economic value left over from a production process after specific contractual obligations have been satisfied. Although the term is used most often in describing relatively complex organizational forms such as corporations, partnerships, and trusts, it has also been used to analyze basic property rights (Barzel 1997, 3). Economists have offered a variety of explanations for why some values are reduced to fixed contractual obligations and others exist as residual claims. One explanation is that the party who is best able to manage risk is designated the residual claimant. Another is that the party who is in the best position to affect the mean value of the asset is made the residual claimant. Most of these accounts have a strong contractarian flavor. They suggest, at least implicitly, that affected parties decide case-by-case how to allocate fixed and residual claims to produce optimal incentives to maximize the value of the production process.

Plausible economic arguments can explain why different patterns of residual claimancy are established in different contexts. And it is also plausible that contractual provisions play a critical role in shifting the identity of the residual claimant from one context to the next. But is it contracts all the way down? The economists, who tend to view property rights in contractarian terms (Merrill and Smith 2001b), often seem to think so. For example, in one article residual claims are defined as a "contract for the rights to net cash flows" (Fama and Jensen 328). The problem with this is that we rarely, if ever, see such a contract. Contracts are used to define relatively specified claims, whereas the residual rights are left unspecified. Oliver Hart (124) has partially broken with this tradition, offering the view that residual claims are "closely connected" with the concept of ownership. But this is vague. Individuals and entities own assets, not residual claims.

Perhaps greater precision can be brought to this line of analysis by introducing the principle of accession. The principle of accession, broadly conceived, means that the owner of an asset will be deemed the owner of any new assets or increments in value prominently connected with that asset. This explains the basic concept of residual claimancy in simple property 
rights contexts. The owner of an asset will be the residual claimant of all derivative assets and increments in value attributable to that asset, after specified contractual obligations are satisfied. This understanding also supplies the baseline against which modifications in the allocation of residual rights by contract are interpreted. In lease law, for example, the baseline understanding is that the tenant, as the party in possession, is the person entitled to capture all gains and losses associated with the asset during the term of the tenant's lease (Paradine v. Jane, [1647] K.B., 82 Eng. Rep. 897). Modifications of this understanding, as by adopting a sharing of these gains and losses between landlord and tenant, require a specific lease provision to the contrary.

As applied to corporations, partnerships, and trusts, recognition of the principle of accession yields the insight that proper identification of the "residual claimant" entails a two-step analysis. First, title to the assets of the firm, the partnership, or the trust is held in the name of the entity itself. Thus, by operation of the principle of accession, any new resources or gains and losses in value, prominently associated with ownership of these assets, belong to the entity and not to anyone else. Second, the division of these accessionary gains and losses among the various actors who have a stake in the entity will be determined by entity law, including permissible contracts. Thus, for example, in determining how the cash flows of a corporation will be distributed among stockholders, bondholders, officers, directors, and the officers' favorite charities, we look to business corporation law and any relevant charter provisions or contractual undertakings of the firm.

This perspective can help resolve the debate over the boundaries of the firm. If we think of the firm as simply a nexus of contracts, the firm dissolves into web of contracts, with no clear line of demarcation between inside and outside (Eisenberg). The principle of accession suggests that the boundary of the firm is established by the assets to which the firm holds title in the name of the firm. Because of the principle of accession, the firm internalizes the benefits and losses from its custodial and transactional activities regarding these assets. The firm can thus be said to be the "residual claimant" of the gains and losses associated with these assets.

The cash flows generated by these activities are then distributed among various stakeholders of the firm according to a different nexus of contracts that governs relations between shareholders, directors, officers, and employees within the firm. The concept of residual claimancy might also be relevant within this internal nexus of contracts; conventionally we say 
that the shareholders are the residual claimants within the internal nexus of contracts. But mixing up the two types of residual claimancy is likely to produce confusion. And it goes without saying that we will need boundary maintenance doctrines to allocate certain assets between the firm and the agents of the firm.

\section{IMPLICATIONS FOR NORMATIVE THEORIES}

I will now switch gears and consider the principle of accession from a different perspective: that of normative theories of property. Although from an efficiency perspective the principle of accession seems largely a positive one, the story is rather different when we turn to normative justifications. Here the implications of accession seem potentially disconcerting, enough so that we perhaps have a clue as to why there has been so much reluctance to grapple with the principle of accession in American literature about property rights.

\section{A. Accession and Desert}

Let us begin with John Locke, still today the point of departure for most philosophical discussions of property (e.g., Waldron, 137-252). Locke unabashedly grounds original ownership of property in first possession, as do his intellectual successors, such as Robert Nozick (at 149-82) and Richard Epstein (1979). Locke suggested that first possession is justified because it involves labor and hence desert, and/or because first possession is responsible for only a trivial portion of the contemporary value of property. Nozick argued that so long as acts of first possession do not leave any person worse off-and ordinarily he thought they do not because they involve the taking of things that no one previously claimed-they are unobjectionable. Epstein has concluded that first possession is justified because it is the method of original acquisition most likely to avoid "extensive and continuous state control" (Epstein 1979, 1239).

For Lockeans in general, the most important fact about first possession is that it entails a volitional act. A person must intentionally do something for which he is presumptively responsible-engage in a performative act-before acquiring something by first possession. I also suspect that first possession is attractive for Lockeans because it appears to be fair, in that it establishes a simple competition for resources open to all. Although luck as well as labor can play a role in determining who initially gets the most 
valuable resources, all persons at least have an equal opportunity in the race for the prize.

The school of thought that can be called Lockean couples this emphasis on first possession with an associated type of argument about how we get from acts of original acquisition to the much wealthier and more complex world we live in today. This associated argument also emphasizes certain volitional acts that individuals take with respect to the objects over which ownership has been established by first possession.

Locke himself stressed the importance of human labor in transforming objects acquired through original possession. In an interesting exercise in armchair empiricism, Locke estimated that " $99 / 100$ " of the value of all resources in contemporary society is due to labor, as opposed to acts of original possession (Locke, 296). Thus, nearly all the value we attribute to property today is due to assiduous husbandry and cultivation; original acquisition is but a tiny detail. The invention of money, according to Locke, played an important role here by permitting large accumulations of wealth attributable to sustained labor without creating problems of spoilage or waste.

More recent accounts, including Nozick's influential restatement of Locke, have emphasized the role of voluntary exchange of rights in moving from first possession to the complex reality of today. Nozick suggested that the contemporary distribution of property is just insofar as it is the product of acts of original possession of unclaimed things followed by voluntary exchanges of the rights so acquired (including exchanges of labor for things). Thus, as long as two conditions are satisfied-justice in acquisition (first possession) and justice in transfer (voluntary exchange)-the current distribution of property is just. ${ }^{26}$ In general, the Lockean conception posits that a just system of property is one built up out of discrete volitional acts of individuals, each of which is morally justified.

The Lockean view of property has been criticized on many grounds, but here I am interested only in the implications of the principle of accession

26 Nozick summarizes his position as follows (151):

If the world were wholly just, the following inductive definition would exhaustively cover the subject of justice in holdings.

1. A person who acquires a holding in accordance with the principle of justice in acquisition is entitled to that holding.

2. A person who acquires a holding in accordance with the principle of justice in transfer, from someone else entitled to the holding, is entitled to the holding.

3. No one is entitled to a holding except by (repeated) applications of 1 and 2 . 
for this view. The principle of accession poses a significant challenge to the Lockean exercise in justification. Accession sweeps into the control of owners of assets all increments in value prominently connected with the asset, including those created by assiduous labor and smart bargaining, but also those that come about because of acts of God, market forces, and other events beyond the contemplation or control of any individual. This means the system of private property includes a substantial element of value that cannot be attributed to any volitional act on the part of the owner or her predecessors in title. The role of luck, which plays only a minor role under first possession-mostly with regard to acts that are now only a distant memory-takes on a pervasive and ongoing role under accession. It is much more difficult to justify a system based in significant part on luck than one grounded solely in volitional acts like first possession, labor, and voluntary exchange.

To make matters worse, the principle of accession means that private property has built into its very operation a set of doctrines that mean the rich get richer. Insofar as new resources are discovered or increments in value become newly salient and we assign these new resources or values to established owners of property, then those who already have significant property continually get more-by operation of law. And those who have less property, or who have no property at all, fall further and further behind. This means that private property has inherently regressive distributional tendencies. These tendencies are not merely the byproduct of some people working harder than others or being better negotiators than others, as Lockeans would like us to believe. Because of the principle of accession, regressive distribution is hard-wired into the very operation of a system of private property.

Thus, it is disappointing but not surprising that Lockeans have ignored the principle of accession in their various accounts of why private property is justified. Accession can be powerfully efficient, but it is problematic on the grounds of individual desert favored by Lockeans.

\section{B. Egalitarian Theories}

Another prominent school of normative scholarship about property is what I call egalitarian (e.g., Ackerman; Dworkin; Murphy and Nagel). Following Bentham, this view posits that property is the product of deliberate state action, not a sequence of individual volitional acts starting in some kind of state of nature. Because property is the product of collective action, the 
touchstone for the design of any property system should be the public welfare, broadly defined to include both incentives for increased output and a distribution of that output that ensures the widest benefit to society. The modern version of this perspective does not call for the abolition of private property, but rather for the institution of government programs that would ensure that everyone has enough property to lead a decent life (e.g., Ackerman and Alstott; Gates, J.; Hockett; Sherraden). These programs would be funded by higher taxes on the more fortunate members of society.

The egalitarians have also overlooked the implications of accession. These theorists are driven primarily by a concern for distributive justice. And it is clear they lack enthusiasm for the institution of property. Thus, it is more than a little strange that they have not attacked the principle of accession as a factor contributing to the unequal distributive outcomes, which is what they find most distasteful about property. Instead these scholars tend to focus almost exclusively on distributional shares of wealth, conceived in the abstract as the power to draw on society's resources for personal consumption. Property is simply a black box whose outcomes for patterns of consumption they do not like. A simple explanation for this indifference to the accessionary feature of property might be that these scholars are just not very interested in how the system of property works-as opposed to its implications. But it is possible that there are deeper causes for the failure to engage with the principle of accession as well.

A possible clue to the source of this silence is provided by the comments of Hugo Grotius, the first of the modern expositors to reflect on the principle of accession. Grotius was generally of the view that accession is contrary to the "law of nature" (Grotius, 298-309). This judgment appears to have been driven by what he regarded as the unfairness of the winner-take-all feature of the Roman doctrines. For example, he wrote (id. 307):

[T] hat a thing of less value should be taken over by one of greater value...is naturally consistent with the facts but not with the right. He in fact who is the owner of one twentieth of an estate remains a part owner as well as the one who has the nineteenth twentieths. Therefore what the Roman law has decreed in some cases, or what may be decreed in others, concerning accession on account of superiority in respect to worth, is not the law of nature but civil law, and has in view the transacting of business more easily.

Grotius offered similar judgments about the rule of increase; the crop rules; and accessio, specificatio, and confusio (id. 306-08). With respect to accretion, 
he seemed to be of the view that the public should be entitled to the new land, insofar as the body of water from which it was formed was subject to public rights (id. 300-01).

Yet Grotius drew back from making any claim that the principle of accession should be abandoned. He explained rather lamely that "the law of nature was not opposed" to accession because the civil law "has the right of conferring ownership" (id. 307). Perhaps more tellingly, his comment that accession makes "the transacting of business" easier suggests he might have perceived that accession is far more efficient than any rule of apportionment or sharing of gains would be.

As we saw in Parts IV and V, the principle of accession has strong efficiency properties. It is the principal mechanism we have for ensuring the proper management and control of resources by internalizing to the gatekeeper-managers of resources the costs and benefits of their decisions about how to deploy these resources. The principle of accession, as a mechanism for internalizing the costs and benefits of managerial decisions taken by the gatekeeper-manger, is obviously overbroad. It sweeps within its compass not only increments in value (or loss) due to the gatekeeper's stewardship and negotiating skills, but also those due to acts of God, market forces, and pure dumb luck. Unfortunately, however, no mechanism has yet been devised for limiting the rewards and punishments of the owner of assets to those attributable to the owner's custodial practices or acts. No perfect Georgian $\operatorname{tax}^{27}$ has been invented that neatly subtracts windfall gains and losses, while leaving in place only those changes in value attributable to individual effort and skill. Until a more precise filtering mechanism of gains and losses is devised, the property strategy must rely on the principle of accession.

The strong efficiency properties associated with accession make it difficult to mount a direct assault on this characteristic of property in an effort to achieve a more egalitarian distribution of outcomes. In particular, consider the implications of any attack on the idea that assets generally have a unique and singular gatekeeper-manager, inspired perhaps by a desire to promote more widespread sharing of the control and benefits of property. This would directly undermine the principle of accession, which internalizes the benefits and costs of management decision on a singular owner to promote efficient stewardship of assets.

27 Henry George was a nineteenth-century economist who argued that all taxes should be based on changes in the value of land, which he regarded as the product of forces unaffected by the exercise of individual choices and effort and hence as imposing no distortions in terms of individual incentives (George). 
Tinkering with the core principles of property in this fashion would threaten to kill the capitalist goose that lays the proverbial golden egg.

Perhaps not surprising, therefore, today's egalitarians-now that the Marxists have largely left the stage-confine themselves to arguing around the edges of property. They expose historic injustices in the acquisition of property. They offer proposals for guaranteed minimal entitlements. They applaud features of the existing system of private property that promote greater community controls over property, such as the regulation of spillovers, limits on dead hand control, public accommodations duties, antidiscrimination laws, and expanded powers of eminent domain. But they offer few proposals for the modification of existing property doctrines. ${ }^{28}$ And there are no proposals that would touch the principle of accession.

The interesting question is whether the ideals of the egalitarians can be realized as long as the core of private property remains intact, including the principle of accession. Accession makes property a powerfully efficient tool for managing resources, but it also creates a built-in multiplier effect that means owners of property continually get more property. The multiplier effect works most strongly with respect to the ownership of things-discrete assets that can be identified as being prominently connected to other discrete assets and values. Insofar as programs of redistribution entail conferring property on the needy in the form of money or other claims on fungible wealth, it is not clear that redistribution can keep up with accession.

In theory, one could account for accession's multiplier effect by calculating the expected differential advantage of accession-eligible assets relative to cash and increasing the amount of cash transfer payments by some bonus to offset this effect. In practice, the calculation would be impossible to develop in any principled fashion, given the incredible variety of assets subject to accession and the difficulty of separating out the portion of additional wealth due to the automatic sweeping feature of accession from the portion due to good management practices (stimulated in part by the incentive effects of accession). And it would be difficult to explain the need for bonus payments to the public.

One lesson for egalitarians therefore might be that programs that put cash in the hands of the poor, such as the Earned Income Credit program of the income tax, have certain disadvantages relative to programs designed to put real assets in the hands of the less fortunate, especially productive

28 For a rare exception, see Dagan and Heller, suggesting that the automatic right of partition should be qualified to promote greater efforts in collaborative ownership of property. 
assets-including enhanced human capital-(De Soto). Forty acres and a mule might have been a superior idea for a redistributive program, relative to cash bounties or adjusting rates of taxation.

\section{Preserving the Public Domain}

A third normative theme invokes the idea of preserving public rights, and in particular the notion that a significant share of resources should remain in an open access state or the public domain. The idea of the public domain has powerful resonance in American culture. Throughout the nineteenth century and into the early decades of the twentieth, a huge land mass known as the public domain-essentially most of the American West-was open to claiming under various first possession-like doctrines, including preemption, homesteading, the Mining Act, appropriative water rights, and even a general privilege to construct roads on public lands (Gates, P.). This public domain was closed, for practical purposes, in 1934 and officially in 1976. But traces of the idea live on. There is still a general presumption of open public access to federal landholdings, even if one cannot claim anything after one gets there. The Wilderness Act, the National Parks Act, and the evolving management conventions associated with the national forests, all suggest strong political support for the idea that big chunks of the public domain should remain free of development, precisely so that this open access state can be preserved-if only for its symbolic value.

Today, the battle cry to save the public domain is more often encountered with respect to intellectual goods, and in particular digital communications, rather than more traditional tangible resources such as forests and tundra (e.g., Benkler; Boyle; Lessig). The basic concern, as Carol Rose has put it, is that we can have "too much property" where intellectual goods are concerned. Because intellectual goods are nonrivalrous, the correct price for such goods, from an allocational perspective, is zero. Any attempt to enforce exclusion rights in such goods, and hence to charge some positive price for access, will cut off access at a suboptimal level. The claim is also made that intellectual creation is a collective enterprise and that "total creativity is enhanced by open access and interaction among all entrants' ideas" (Rose 1998, 153).

I am not interested here with whether or to what extent claims of Larry Lessig and others that we are experiencing a rapid "enclosure" of the public domain are true. The only point I wish to make is that the principle of accession, insofar as it applies to intellectual goods, inevitably contributes 
to a shrinking of the public domain. The scope of copyright is magnified by derivative rights, which necessarily reduce the remaining sphere of the public domain. Indeed, Lessig has specifically attacked the doctrine of derivative rights in copyright as one of the factors threatening "enclosure" of the public domain (Lessig, 294-95). The same point applies to patent improvements, trademarks protected by anti-dilution provisions, and publicity rights. Thus, we have another reason to worry about the normative implications of the principle of accession.

In short, the principle of accession is a problematic feature of property from a normative perspective. It is centrally responsible for the efficiency of property, but makes it more difficult to justify property using commonly shared moral perspectives. Because it appears we cannot live without the principle of accession, the attempts to justify the existing system of private property, or to describe an alternative vision of an ideal system of property, will remain stunted and incomplete as long as this principle is ignored.

\section{CONCLUSION}

I have covered a lot of ground, the justification being that the principle of accession is largely terra incognita insofar as American property scholars are concerned. The central propositions I have sought to advance are that the principle of accession is a distinctive means of acquiring original ownership of property; that accession is widespread and in fact ubiquitous; that accession is almost certainly more efficient than first possession in circumstances where property rights are reasonably thick; that accession awards new resources to prominently connected owners because this saves on information costs and selects as owners persons who are generally fit; and that accession plays a critical role in establishing the internalization function that makes property such a valuable tool for resource management. I have also suggested that the principle of accession highlights a deep tension in the structure of property rights between the efficiency-promoting aspects of property and the normative implications of property. I have made no effort to resolve that tension or to indicate what qualifications, if any, should be made to the principle of accession to trade off some efficiency for greater equity. I am skeptical that any such modifications would be desirable. But the case in support of that judgment must wait another day. 


\section{REFERENCES}

Abramowicz, Michael. "A Theory of Copyright's Derivative Right and Related Doctrines." Minnesota Law Review 90 (2005): 317.

“The Uneasy Case for Patent Races over Auctions." Stanford Law Review 60 (2007): 803.

Ackerman, Bruce. Social Justice in the Liberal State. New Haven: Yale U. Press, 1980.

Ackerman, Bruce and Anne Alstott. The Stakeholder Society. New Haven: Yale University Press, 1999.

Alchian, Armen A. and Harold Demsetz. "Production, Information Costs, and Economic Organization." American Economic Review 62 (1972): 777.

Alexander, Gregory. Commodity and Propriety: Competing Visions of Property in American Legal Thought. Chicago: University of Chicago Press, 1997.

Anderson, Terry L. and Peter J. Hill. "The Evolution of Property Rights: A Study of the American West." Journal of Law and Economics 18 (1975): 163.

“The Race for Property Rights." Journal of Law and Economics 33 (1990): 177.

“Cowboys and Contracts." Journal of Legal Studies 31 (2002): S489.

Arnold, Earl C. “The Law of Accession of Personal Property." Columbia Law Review 22 (1922): 103.

Barzel, Yoram. "Optimal Timing of Innovations." Review of Economics and Statistics 50 (1968): 348.

Economic Analysis of Property Rights. 2d ed. New York: Cambridge U. Press, 1997.

Benkler, Yochai. "Free as the Air to Common Use: First Amendment Constraints on Enclosure of the Public Domain." New York University Law Review 74 (1999): 354.

Bentham, Jeremy. Theory of Legislation (R. Hildreth trans., 1908). London: Kegan Paul.

Blackstone, William. Commentaries on the Laws of England. Chicago: University of Chicago Press (Facsimile ed. 1979), 1766.

Bohn, Henning and Robert T. Deacon. "Ownership Risk, Investment and the Use of Natural Resources." American Economic Review 90 (2000): 526. 
Boyle, James. "The Second Enclosure Movement and the Construction of the Public Domain.” Law and Contemporary Problems 66 (2003): 33.

Broder, John. "Schwarzennegger Files Suit Against Bobblehead Maker.” New York Times, May 18, 2004, A16.

Brown, Ray Allen. A Treatise on the Law of Personal Property, 1st ed., 1936.

Brown, Ray Allen. A Treatise on the Law of Personal Property, 4th ed., 1955.

Carroll, Andrea B. "Examining a Comparative Law Myth: Two Hundred Years of Riparian Misconception." Tulane Law Review 80 (2006): 901.

Coase, R.H. “The Problem of Social Cost.” Journal of Law and Economics 3 (1960): 1 .

Cohen, Felix. “Dialogue on Private Property." Rutgers Law Review 9 (1954): 357.

Cooter, Robert and Thomas Ulen. Law and Economics. Glenview, Ill.: Scott Foresman and Co., 1988.

Dagan, Hanoch and Michel A. Heller. “The Liberal Commons.” Yale Law Journal 110 (2001): 549.

De Alessi, Loius. "Gains from Private Property: The Empirical Evidence" in Property Rights: Cooperation, Conflict, and Law (Terry L. Anderson and Fred S. McChesney eds.). Princeton, N.J: Princeton U. Press, 2003.

Demsetz, Harold. “Toward a Theory of Property Rights." American Economic Review 57 (1967): 347 (Papers and Proceedings).

De Soto, Hernando. The Mystery of Capital. New York: Basic Books, 2000.

Duffy, John F. "Rethinking the Prospect Theory of Patents." University of Chicago Law Review 71 (2004): 439.

Dworkin, Ronald. Sovereign Virtue: The Theory and Practice of Equality. Cambridge: Harvard U. Press, 2000.

Eggertsson, Thrainn. "Open Access versus Common Property, in Property Rights: Cooperation, Conflict, and Law." (Terry L. Anderson and Fred S. McChesney eds.). Princeton: Princeton U. Press, 2003.

Eisenberg, Melvin A. "The Conception That the Corporation is a Nexus of Contracts, and the Dual Nature of the Firm." Journal Corporate Law 24 (1999): 819.

Ellickson, Robert C. "A Hypothesis of Wealth-Maximizing Norms: Evidence from the Whaling Industy." Journal of Law, Economics and Organization 5 (1989): 83.

-Order without Law: How Neighbors Settle Disputes. Cambridge: Harvard U. Press, 1991.

“Property in Land.” Yale Law Journal 102 (1993): 1315. 
Epstein, Richard A. "Possession as the Root of Title." Georgia Law Review 13 (1979): 1221.

“The Public Trust Doctrine." Cato Journal 7 (1987): 411.

"The Allocation of the Commons: Parking on Public Roads." Journal of Legal Studies 31 (2002): S515.

Fama, Eugene F. and Michael C. Jensen. "Agency Problems and Residual Claims." Journal of Law and Economics 26 (1983): 327.

Fennell, Lee Anne. "Common Interest Tragedies." Northwestern University Law Review 98 (2004): 907.

Frisch, David. "UCC Section 9-315: A Historical and Modern Perspective." Minnesota Law Review 70 (1985): 1.

Gates, Jeff. The Ownership Solution: Toward a Shared Capitalism for the 21st Century. New York: Basic Books, 1998.

Gates, Paul W. History of Public Land Law Development. Washington, D.C.: Zenger Pub. Co., 1968.

Gerstenblith, Patty. "Identity and Cultural Property: The Protection of Cultural Property in the United States." Boston University Law Review 75 (1995): 559.

George, Henry. Progress and Poverty. Garden City, N.Y.: Doubleday, 1879.

Goble, Dale D. and Eric T. Freyfogle. Wildlife Law. New York: Foundation Press, 2002.

Grady, Mark F. "A Positive Economic Theory of the Right of Publicity." UCLA Entertainment Law Review 1 (1994): 97.

Grady, Mark F. and Jay I. Alexander. "Patent Law and Rent Dissipation." Virginia Law Review 78 (1992): 305.

Grotius, Hugo. De Jure Belli Ac Pacis Libri Tres (Francis W. Kelsey, trans. 1925). New York: Bobbs Merrill, 1646.

Haddock, David D. "First Possession Versus Optimal Timing: Limiting the Dissipation of Economic Value." Washington University Law Quarterly 64 (1986): 775.

Hardin, Garrett. "The Tragedy of the Commons." Science 162 (1968): 1243. Hart, Oliver D. "Incomplete Contracts and the Theory of the Firm." Journal of Law, Economics and Organization. 4 (1988): 119.

Hartog, Hendrik. Public Property and Private Power. Ithaca, N.Y.: Cornell U. Press, 1983.

Hazlett, Thomas W. Assigning Property Rights to Radio Spectrum Users: Why Did FCC License Auctions Take 67 Years?" Journal of Law and Economics. 41 (1998): 529. 
Heller, Michael. The Gridlock Economy. New York: Basic Books, 2008.

Helmholz, R.H. "Equitable Division and the Law of Finders.” Fordham Law Review 52 (1983): 313.

Hockett, Robert. "Whose Ownership? Which Society?.” Cardozo Law Review 27 (2005): 1.

Holmes, Oliver Wendell. The Common Law (Mark DeWolfe Howe ed. 1963). Boston: Little Brown, 1881.

Hume, David. A Treatise of Human Nature (L.A. Shelby-Bigge, ed. 1888). London: Oxford University Press, 1739.

Jensen, Michael C. and William H. Meckling. "Theory of the Firm: Managerial Behavior, Agency Costs and Owenrship Structure.” Journal of Financial Economics. 3 (1976): 305.

Kearney, Joseph D. and Thomas W. Merrill. "The Origins of the American Public Trust Doctrine: What Really Happened in Illinois Central." University of Chicago Law Review 71 (2004): 799.

Kiew, Chiawen C., Comment, "Contracts, Combinations, Conspiracies, and Conservation: Antitrust in Oil Unitization and the Intertemporal Problem." Northweswtern University Law Review 99 (2005): 931.

Kitch, Edmund W. “The Nature and Function of the Patent System.” Journal of Law and Economics 20 (1977): 265.

Lemley, Mark A. “The Economics of Improvement in Intellectual Property Law.” Texas Law Review 75 (1997): 989.

“Ex Ante Versus Ex Post Justifications for Intellectual Property." University of Chicago Law Review 71 (2004): 129.

Lessig, Lawrence. Free Culture: How Big Media Uses Technology and the Law to Lock Down Culture and Control Creativity. New York: Penguin Press, 2004.

Libecap, Gary D. Contracting for Property Rights. New York: Cambridge University Press, 1989.

Locke, John. Two Treatises of Government (Peter Laslett ed. 1988). New York: Cambridge University Press, 1689.

Long, Clarisa. “Dilution.” Columbia Law Review 106 (2006): 1029.

Lueck, Dean. "The Rule of First Possession and the Design of the Law." Journal of Law and Economics 38 (1995): 393.

“The Economic Nature of Wildlife Law.” Journal of Legal Studies 18 (1989): 291.

Lund, Thomas A. "British Wildlife Law Before the American Revolution: Lessons from the Past.” Michigan Law Review 74 (1975): 49. 
Merges, Robert P. and Richard R. Nelson. "On the Complex Economics of Patent Scope." Columbia Law Review 90 (1990): 839.

Merrill, Thomas W. and Henry E. Smith. "Optimal Standardization in the Law of Property: The Numerus Clausus Principle.” Yale Law Journal 110 (2000): 1 .

“The Property/Contract Interface." Columbia Law Review 101 (2001): 773.

"What Happened to Property in Law and Economics?" Yale Law Journal 111 (2001): 357.

“Property and Morality." William and Mary Law Review 48 (2007): 1849.

Mortensen, Dale T. "Property Rights in Mating, Racing, and Related Games." American Economic Review 72 (1982): 968.

Murphy, Liam and Thomas Nagel. The Myth of Ownership: Taxes and Justice. New York: Oxford University Press, 2004.

Nozick, Robert. Anarchy, State, and Utopia. New York: Basic Books, 1974.

Ostrom, Elinor. Governing the Commons: The Evolution of Institutions for Collective Action. New York: Cambridge University Press, 1990.

Pufendorf, Samuel. De Jure Naturae et Gentium Libri Octo (C. H. Oldfather and W.A. Oldfather, trans. 1934). New York: Oceana, 1688.

Rose, Carol M. "Possession as the Origin of Property." University of Chicago Law Review 52 (1985): 73.

"The Several Futures of Property: Of Cyberspace and Folk Tales, Emission Trades and Ecosystems.” Minnesota Law Review 83 (1998): 129.

Rubenfeld, Jed. “The Freedom of Imagination: Copyright's Constitutionality." Yale Law Journal 112 (2002): 1.

Sherraden, Michael W. Assets and the Poor: A New American Welfare Policy. Armonk, NY: M.E. Sharpe, 1991.

Shaham, Erez and Noam Sher. "A Purchaser of a Product V. an Owner of Stolen Intellectual Property: The Revival of the Accession Rule." Whittier Law Review 28 (2006): 319.

Singer, William Joseph. Entitlement: The Paradoxes of Property. New Haven: Yale University Press, 2000.

Slater, R. B. "Accessio, Specificatio and Confusio: Three Skeletons in the Closet." Canandian Bar Review 37 (1959): 597.

Signon, Mark R., Note, "Hunting and Posting on Private Land in America." Duke LawJournal 54 (2004): 549. 
Smith, Henry E. "Exclusion Versus Governance: Two Strategies for Delineating Property Rights." Journal of Legal Studies 31 (2002): S453. "The Language of Property: Form, Context, and Audience." Stanford Law Review 55 (2003): 1105. "Intellectual Property as Property: Delineating Entitlements in Information." Yale Law Journal 116 (2007): 1742.

Squillante, Alphonse M. "The Law Of Fixtures: Common Law and the Uniform Commercial Code, Part I: Common Law of Fixtures." Hofstra Law Review 15 (1987): 191.

Sugden, Robert. The Economics of Rights, Co-operation and Welfare. Oxford: B. Blackwell, 1986.

Tullock, Gordon. "The Welfare Costs of Tariffs, Monopolies, and Theft." Western Economic Journal 5 (1967): 224.

Umbeck, John. "The California Gold Rush: A Study of Emerging Property Rights." Explorations in Economic History 14 (1977): 197.

U.N. Food and Agriculture Organization. "The State of the World's Fisheries and Acquaculture", 2000.

Van Vliet, L.P.W. “Accession of Movables to Land.” Edinburgh Law Review 6 (2002): 67.

Waldron, Jeremy. The Right to Private Property. New York: Oxford University Press, 1988.

Wyman, Katrina Miriam. "From Fur to Fish: Reconsidering the Evolution of Private Property." New York University Law Review 80 (2005): 117.

Wu, Tim. "Intellectual Property, Innovation, and Decentralized Decisions." Virginia Law Review 92 (2006): 123. 


\section{JLA $\mid$ Journal of Legal Analysis}

Ayotte, Morrison, Creditor Control and Conflict in Chapter 11

Summer, 2009: Volume 1, Number 2

This online journal is licensed under a Creative Commons

Attribution-Noncommercial-Share Alike 3.0 Unported License

http://jla.hup.harvard.edu 
